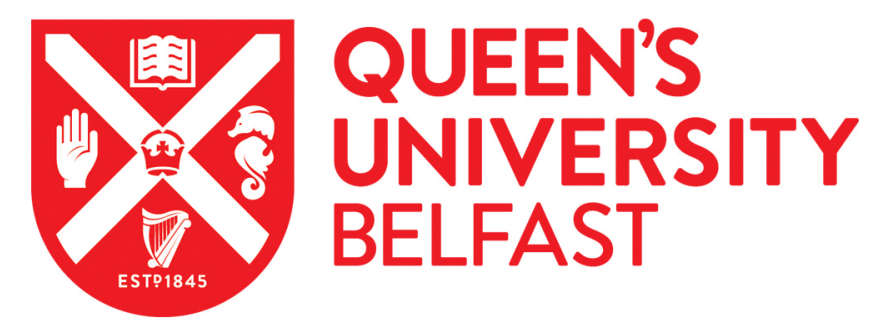

\title{
Improvements in single-use bioreactor film material composition leads to robust and reliable Chinese hamster ovary cell performance
}

\author{
Harper, E., Connolly, L., Kelly, P. S., Dorival-García, N., Paré, S., Carillo, S., Ta, C., Alarcon Miguez, A., \\ Coleman, O., Shannon, M., Henry, M., Clynes, M., Meleady, P., Bones, J., \& Barron, N. (2019). Improvements in \\ single-use bioreactor film material composition leads to robust and reliable Chinese hamster ovary cell \\ performance. Biotechnology Progress, 35(4), e2824. [35]. https://doi.org/10.1002/btpr.2824, \\ https://doi.org/10.1002/btpr.2824 \\ Published in: \\ Biotechnology Progress
}

Document Version:

Peer reviewed version

Queen's University Belfast - Research Portal:

Link to publication record in Queen's University Belfast Research Portal

\section{Publisher rights}

(C) 2019 American Institute of Chemical Engineers.

This work is made available online in accordance with the publisher's policies. Please refer to any applicable terms of use of the publisher.

\section{General rights}

Copyright for the publications made accessible via the Queen's University Belfast Research Portal is retained by the author(s) and / or other copyright owners and it is a condition of accessing these publications that users recognise and abide by the legal requirements associated with these rights.

Take down policy

The Research Portal is Queen's institutional repository that provides access to Queen's research output. Every effort has been made to ensure that content in the Research Portal does not infringe any person's rights, or applicable UK laws. If you discover content in the Research Portal that you believe breaches copyright or violates any law, please contact openaccess@qub.ac.uk. 


\section{Research article - Biotechnology Progress}

Improvements in single-use bioreactor film material composition leads to robust and reliable Chinese hamster ovary cell performance

Paul S Kelly ${ }^{1,5, \dagger}$, Noemi Dorival-García ${ }^{1,5, \dagger}$, Samantha Paré2,5, Sara Carillo ${ }^{1,5}$, Christine Ta ${ }^{1,5}$, Antonio Alarcon Miguez ${ }^{2}$, Orla Coleman², Emma Harper ${ }^{4}$, Maeve Shannon ${ }^{4}$, Michael Henry ${ }^{2}$, Lisa Connolly ${ }^{4}$, Martin Clynes ${ }^{2,5}$, Paula Meleady ${ }^{2,5}$, Jonathan Bones ${ }^{1,5, \dagger}$ and Niall Barron ${ }^{1,3,5, \dagger, *}$

1 National nstitute for Bioprocessing Research and Training, Fosters Avenue, Mount Merrion, Blackrock, Co. Dublin, Ireland.

2 National Institute for Cellular Biotechnology, Dublin City University, Glasnevin, Dublin 9, Ireland.

${ }^{3}$ School of $O$ emical and Bioprocess Engineering, University College Dublin, Dublin 4.

${ }^{4}$ Institute for. Global Food Security, School of Biological Sciences, Queen's University, Belfast, Northern Ireland, United Kingdom.

${ }^{5}$ Syn. resis and Solid State Pharmaceutical Centre, University of Limerick, Ireland.

$\dagger$ Authors co tributed equally

* C. resr onding author

1

Email:niall.barron@nibrt.ie

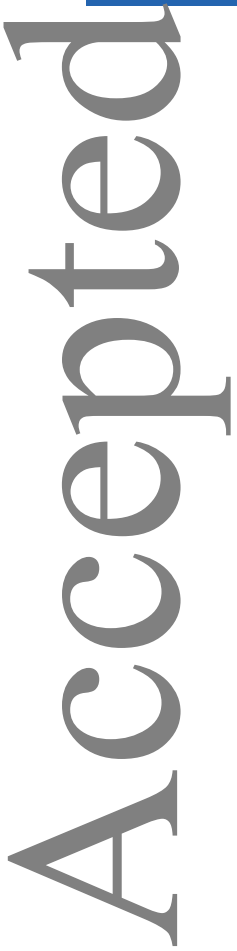

This article has been accepted for publication and undergone full peer review but has not been through the copyediting, typesetting, pagination and proofreading process which may lead to differences between this version and the Version of Record. Please cite this article as 


\section{$\underline{\text { Abstract }}$}

Single-use technologies, in particular disposable bioreactor bags, have become integral within the biopharmaceutical community. However, safety concerns arose upon the identification of toxic leachable compounds derived from the plastic materials. Although the leachable bis(2,4-di-tert-butylphenyl)-phosphate (bDtBPP) has been previously shown to inhibit CHO cell growth, it is critical to determine if other compounds like this are still present in subsequent generations of films for industrial applicatio . This study compares the performance of $\mathrm{CHO}$ cells, $\mathrm{CHO}-\mathrm{K} 1$ and $\mathrm{CHO}$ DD1? mit/red in media conditioned in an older single-use bioreactor (SUB) film (F-1) and newer generation film (F-2) from the same vendor. $\mathrm{CHO}$ cells cultured in media condit:...d for 7 days in the F-1 film demonstrated significantly reduced growth and antibody productivity profiles when compared to controls and media conditioned for the s.me tume period in the newer F-2 film. Proteomic profiling of CHO cells cultured in the 1 nditioned media identified differentially expressed proteins involved in oxidativ tress response as well as compromised ATP synthesis. These potentially metaho ically compromised cells exhibited reduced oxidative phosphorylation activity as well as lower glycolytic metabolism, characteristic of slower growing cells. Nonvolatile an'd metal leachables analysis of film extracts by LC-MS revealed a reduction in the ahund ance of the analysed leachates from F-2 films when compared to F-1 films inclu nng DPPP, potentially explaining improved $\mathrm{CHO}$ cell growth in F-2 conditioned media. rurthermore, in vitro endocrine disruptor testing of the known leachable revealed this molecule to possess the potential to act as an androgen antagonist. This stud demonstrates an improvement in the materials composition used in modern generations of SUBs for safe application in the bioprocess.

Keywon. Single-use bioreactors, Leachables, Chinese hamster ovary cells, Endocrine disruftor, \& DtBPP, Mitochondria, SeaHorse XF96 


\section{Introduction}

With the emergence of novel bio-therapeutics, the advent of bio-similars and the increasing number of lead molecules within the developmental pipelines, the notion of individual manufacturing sites being constructed at a cost of $\sim € 1$ billion for every newly approved product is not sustainable ${ }^{1}$. Increasing the flexibility of these manufacturing sites leading to the introduction of multi-drug facilities has been accomplished in certain cases through the implementation and integration of single-use disposable technology in place of or in parallel with exis ng stainless steel, hard-piped production platforms. Applying single-use technoloov to the bioprocessing pipeline carries with it a cohort of potential benefits inclur'ng reduced CapEx of up to $75 \%$, elimination of clean-in-place/steam-in-place treatmu., thereby reducing operational costs, as well as minimising the environmental carbon toouprint ${ }^{2,3}$. Although the size limitations of SUBs $(2,500 \mathrm{~L})$ does not compete with their stamless steel bioreactor counterparts (10-25k L), continuous bioprocessing, perfusionbasec huous bioproduction, upstream seed trains and mixed-use facilities in addition to buffer/m a holding are all key advantages supported by single-use systems ${ }^{4}$.

The Chinese hamster ovary $(\mathrm{CHO})$ cell is the predominant cell line used in the production of recombinant therapeutic proteins for the last 3 decades ${ }^{5}$. Advancements in the areas of cell liic crercpment, bioprocess design and media composition has allowed for the multigram/L nues that we routinely see today, opposed to the $\mathrm{mg} / \mathrm{L}$ of the $1980 \mathrm{~s}$. Pragmatically, these $1 \mathrm{c} w$ t tres have contributed to the requirement of large-scale fermenters that remain the standard un it of operation today. Despite the limitation in SUB size, further boosting the $\mathrm{g} / \mathrm{L}$ titres f.m $\mathrm{CHO}$ cultures could mediate similar outputs from SUB batch cultures compared to

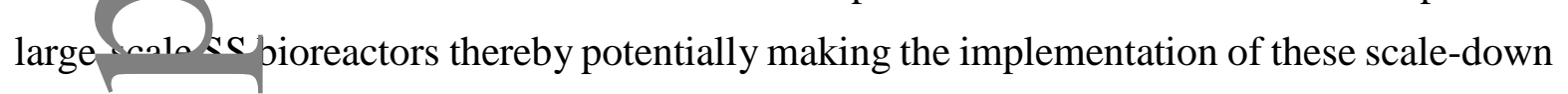
syste $m$ re tangible ${ }^{6}$. Of course with novel and more bespoke biologics being developed, difficult-to-express proteins are a constant challenge to the industry and remain a driving forcefor th generation of more sophisticated production $\mathrm{CHO}$ cell lines via approaches such as micoRVA engineering ${ }^{7}$, genetic knockouts ${ }^{8}$, removing unnecessary genomic burdens ${ }^{9}$ and enn...ing promoter performance ${ }^{10}$.

On na or concern associated with SU technology within the biomanufacturing space is the lack of cra ity surrounding the leachable profiling from these predominantly polyethylenebased plastics. Previous reports with regards to the interaction of these plastics with media components such as cholesterol adsorption resulting in inhibited NSO cell growth ${ }^{11}$ as well as 
chemical transformations introducing potentially toxic leachables into the culture media raises further concerns relating to any new material entering the bioprocessing pipeline. Routinely, additives are required for efficient processing and manufacturing of the plastic films such as the secondary anti-oxidant $\operatorname{Irgafos}^{\circledR} 168$ which upon gamma-irradiation becomes oxidised and subsequently breaks down to leach degradation products into the culture media ${ }^{12}$. The optimal culture environment within the bioreactor is critical to $\mathrm{CHO}$ cell performance and can be compromised by these leachable compounds that can be poter allly toxic. For example, bis(2,4-di-tert-butylphenyl)-phosphate or bDtBPP was initially reported by Hammond and colleagues in $2013{ }^{13}$. Originating from the secondary anti-oxidant $\operatorname{Irgafos}^{\circledR} 168$ or tris(2,4-di-tert-butylphenyl)-phosphite, bDtBPP was reported to

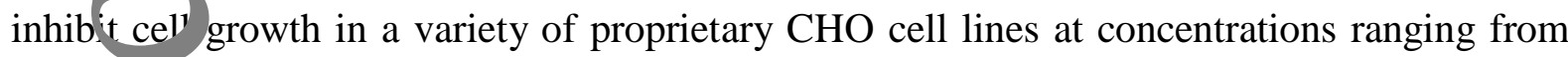
$0 d 2-1 \mathrm{~g} / \mathrm{L}^{14}$. More recently, studies from our group found this leachate to be toxic at far lown concentration range that has been observed to leach and accumulate under ambient conditions over a tim ${ }^{1}$ period of 3-4 days $(0.025-0.11 \mathrm{mg} / \mathrm{L})^{14}$.

Leachah le components such as bDtBPP have been reported to negatively impact cell culture performance not only in terms of growth/viability, but also titre or product quality 16 . $\mathrm{A}^{1+1}$ would be advantageous to know the material composition so that potential causes may a duated, this information is usually not completely available from manufacturers. Also (aue the complexity of the bag manufacturing process, it is difficult to determine the exact composition of most bag films. However, it is known that degradation of the polymers and additives in SUBs occur most significantly during high-energy processes, namely sterilization ${ }^{17}$ and film extrusion ${ }^{18}$, which may produce degradation products such as bDtB ${ }^{\text {PD }}$, whose potential effects on cells maybe completely overlooked. This reality, combin with the low concentrations reported to elicit negative effects on cell growth makes it paamou th that the appropriate solvent systems and analytical techniques for extractables and leachables (E\&Ls) screening are being implemented that are sensitive enough to detect both fow sundant leachates as well as capturing all leachables present ${ }^{19,20}$.

Incr $\leadsto$ d understanding and characterisation of both the leachables profile from SUBs and their efrocts on cells is needed. At present, there are some standardised cell culture tests available $^{21,22}$ to assess the biocompatibility and safety of production cell lines ${ }^{22,23}$, which will assist both bag manufacturers in developing and qualifying new bag films, and end-users to proactively select bags to be used in their processes. However, considering that cell lines 
show different sensitivities to leachables components ${ }^{22}$, developing widely applicable cell culture tests is not a trivial exercise, but it would, however, be desirable, so that vendors and users can apply them with confidence and avoid unwanted false-positive results ${ }^{23}$.

In addition, besides cell culture tests, plastic films used in biomanufacturing should also report leachables assessments in order to be considered fully characterised for their compatibility and safety in relation to cell culture performance as the cocktail of potential leachates other than bDtBPP could pose a problem. Although there is now a greater awareness of the use of single-use components in biomanufacturing, a comprehensive chomoniontion at all levels, both biological and chemical, should be an inevitable requi ment for these SUBs to be available in the market. A large-scale assessment of E\&Ls from 3r single-use plastic films used in cell cultivation has highlighted that the spectrum of E\&Lshas changed due to the introduction of new types of polymers as well as manufacturing changes ${ }^{0}$, whose potential biological effects should be addressed. In view of this, new regulaturis and standardised guidelines should be established by official institutions such as the Foo and Drug Administration (FDA) and United States Pharmacopeia (USP), working in collaboration with industry groups such as BioProcess Systems Alliance (BPSA), the Parenteral Drug Association (PDA), the Product Quality Research Institute (PQRI), Dechema at rum Operation Group (BPOG) ${ }^{24}$.

In this study we performed a comprehensive examination of the impact of newer materials on both the 1 chables profile as well as the influence these materials had on $\mathrm{CHO}$ cell growth. Two the same vendor were chosen, a newer generation film that was designed with lower levels of $\operatorname{Irgafos}^{\circledR} 168$ compared to one of its predecessors $(\mathrm{F}-1)$. This strategy used by bag manufacturers would ultimately reduce the amoln1 of he toxic bDtBPP that could potentially leach into the contacting media. Culture mediawas conditioned in each film as a means to capture the leachates derived from each plastion subsequent growth profiling of two CHO cell lines. Leachable profiling of these two $1 \mathrm{lms}$ ) conjunction with cell-based assays using the same conditioned media afforded the ability to directly compare cellular performance and leachables content with particular em asis on changes within the identified leachates, keeping known toxic leachables like bDtBPP 1 mind. This work also provides information about other sensitive tests that might be included with a view to the development of standardised culture cell tests that would enable the early identification of non-satisfactory films for cultivation of $\mathrm{CHO}$ cell lines in 
chemically defined media. We also demonstrate that leachables can potentially act as endocrine disruptors.

\section{Materials and Methods}

\subsection{Single-use bioreactors (SUBs) used in this study}

Materials from two model generations of the same brand of SUBs (F-1 and F-2) were evaluated. These were multilayer films containing linear low density polyethylene as the fluid contact lay $r$ and ethylene-vinyl acetate as the gas barrier and outer layers. The model F-1 is an old version of this film while F-2 is a more recent version.

\section{() \\ $2 \Omega C_{\text {and }}$ ned media generation}

F-1 and F-2 SUBs (10 L total volume) were incubated with $2 \mathrm{~L}$ of the chemically defined BalaneD CHO Growth A media (Irvine Scientific ${ }^{\circledR}$ ) in the presence of $1 \%$ penicil1. arsireptomycin solution (Sigma-Aldrich). Sealed bioreactors were incubated on a Biosta ${ }^{\circledR}$ rocking motion incubator (Sartorius); temperature was set at $37{ }^{\circ} \mathrm{C}$ and the incubation was carried out for a duration of 3 or 7 days. To ensure good mixing and complete cen bioreactors films, no inflation was used during the incubation and optimum speed max rotation angle were used thus minimizing foam formation. Negative controls were gener ted, incubating $2 \mathrm{~L}$ of media in the presence of $1 \%$ penicillin/streptomycin in prerinsed and autoclaved grade A glass bottles, using the same conditions for incubation. Additionally, the same tubing was used to fill the bags as was used to fill the bottles for consistence nurposes. Incubation with SUBs was performed in triplicate using bags from the same roà yction lot. Negative controls were generated in triplicate as well. At the end of incubation time, all media samples were stored in the original plastic bottles at $4{ }^{\circ} \mathrm{C}$. The labile com onent L-glutamine (Thermo Fisher Scientific) was added to the media after condj+oning and just prior to setting up cell cultures.

\subsection{Cull Culture Conditions and Growth/toxicity assays}

A parental non-producing CHO-K1 (ATCC ${ }^{\circledR}$ CCL-61 ${ }^{\mathrm{TM}}$ ) and an IgG-producing CHO-DP12 (ATCC ${ }^{\circledR}$ CRL-12445 ${ }^{\mathrm{TM}}$ Clone \#1934) cell line was routinely cultured in chemically defined media, BalanCD CHO Growth A, supplemented with $4 \mathrm{mM} \mathrm{L-Glutamine}$ and the anti- 
clumping agent $2 \%$ polyvinyl alcohol. CHO-DP12 cells were maintained stable by pulsing, every 3 passages, with $200 \mathrm{nM}$ of methotrexate (Sigma-Aldrich). Cell assays were inoculated at a starting cell density of $2 \times 10^{5}$ cells $/ \mathrm{mL}$ in a $5 \mathrm{~mL}$ volume in a $50 \mathrm{~mL}$ filtered-topped tube (Helena BioSciences Europe) and maintained under ambient culture conditions of $37^{\circ} \mathrm{C}, 5 \%$ $\mathrm{CO}_{2}$ and $170 \mathrm{rpm}$. Viable cell density and cellular viability was assessed using a benchtop flow cytometer, Guava EasyCyte 5HT system (Millipore, Billerica, MA) in combination with the ViaCount assay (Millipore) as per manufacturer's specifications. Additionally, metal ion scree Alng vas performed using the following metal salts; Lead Nitrate, Silver Nitrate, Nickle(II) Chloride Hexadydrate, Sodium Molybdate dihydrate and Aluminium Chloride (Sigma-Aldrich), all dissolved in water and screened at a concentration of $1 \mathrm{mg} / \mathrm{mL}$ based on the mflec ar weight of the metal and not the salt.

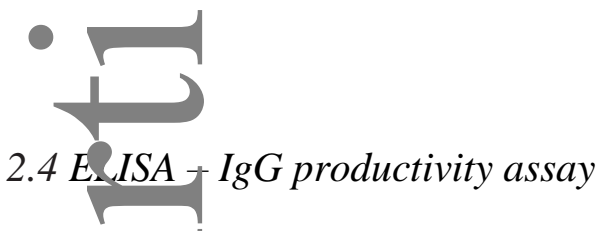

CHO-D IgG oor taining supernatant was decanted and samples were diluted appropriately for each time point in diluent buffer. The ELISA work-flow was carried out in accordance with the manufacturer's specifications (Bethyl Laboratories).

\subsection{Levable testing on conditioned media \\ )}

Non-tarated analyses were performed for identification of non-volatile leachables by LCMS. Fxtrote were treated using DLLME ${ }^{25}$ to remove surfactants and other matrix comp glenty present in the media that could cause ion suppression. HRAM full-scan MS analyses was performed on a Thermo Scientific ${ }^{\mathrm{TM}}$ UltiMate $^{\mathrm{TM}} 3000 \mathrm{RS}$ coupled to a Thermo Sciertific ${ }^{\mathrm{T}} \mathrm{Q}$ Exactive ${ }^{\mathrm{TM}}$ Plus mass spectrometer with HESI-II interface ${ }^{20}$. Resulting HRA I data were processed with Compound Discoverer ${ }^{\mathrm{TM}} 2.0$, followed by automatic online library uarch against mzCloud.org advanced mass spectral database (HighChem) and Chems aur (Royal Society of Chemistry), as well as a local E\&L compound database. Mass Frontiv $7.9^{\mathrm{TM}}$ software was used to determine most probable structures if several options for components were returned. For each proposed structure, the 'Fragments and Mechanisms' feature in Mass Frontier was used to generate predicted 'fragments and mechanisms' through 
the HighChem Fragmentation Library ${ }^{\mathrm{TM}}$ searching. A high degree of correlation between predicted and experimental fragments was required to confirm the proposed structure.

A multi-element determination was also performed on the extracts by ICP-MS. Extracts were acidified with a mixture of $2 \%(\mathrm{v} / \mathrm{v}) \mathrm{HNO}_{3}$ and $0.5 \%(\mathrm{v} / \mathrm{v}) \mathrm{HCl}$, in 1:9 sample/acid (v/v) prior to analysis. All 30 analytes, ${ }^{75} \mathrm{As},{ }^{111} \mathrm{Cd},{ }^{202} \mathrm{Hg},{ }^{208} \mathrm{~Pb},{ }^{7} \mathrm{Li},{ }^{52} \mathrm{Cr},{ }^{60} \mathrm{Ni},{ }^{63} \mathrm{Cu},{ }^{118} \mathrm{Sn},{ }^{121} \mathrm{Sb},{ }^{137} \mathrm{Ba}$, ${ }^{27} \mathrm{Al},{ }^{55} \mathrm{Mn},{ }^{56} \mathrm{Fe},{ }^{66} \mathrm{Zn},{ }^{51} \mathrm{~V},{ }^{59} \mathrm{Co},{ }^{78} \mathrm{Se},{ }^{95} \mathrm{Mo},{ }^{101} \mathrm{Ru},{ }^{103} \mathrm{Rh},{ }^{105} \mathrm{Pd},{ }^{107} \mathrm{Ag},{ }^{189} \mathrm{Os},{ }^{193} \mathrm{Ir},{ }^{195} \mathrm{Pt}$, ${ }^{197} \mathrm{Au},{ }^{205} \mathrm{Tl},{ }^{88} \mathrm{Sr}$, and ${ }^{209} \mathrm{Bi}$, were measured with a Thermo Scientific ${ }^{\mathrm{TM}}$ iCAPTM RQ ICP-MS, accor ang $)$ a previous study ${ }^{20}$. Elemental concentration was determined using calibration curves from multi-elemental standards.

2.6 Enaocrine disruptor testing of bDtBPP

-

2.6 1 Coll $>$ ulture

All call lines were grown in $75 \mathrm{~cm}^{2}$ tissue culture flasks (Nunc, Roskilde, Denmark) at $37^{\circ} \mathrm{C}$ with $5 \% \mathrm{CO}_{2}$ and $95 \%$ humidity. The human adrenal carcinoma (H295R, ATCC) cell line W 100 inely cultured in H295R cell culture medium containing Dulbecco's modified Eagle medium (D/MEM, Life Technologies) with Ham's F-12 nutrient mixture (1:1) supplemented with $1 \%$ ITS + Premix (BD Biosciences) and 2.5\% NuSerum (BD Biosciences). The H295R cells were seeded in H295R assay media composed of DMEM with Ham's F-12 nutrient mixture (1:1) supplemented with 1\% ITS + Premix and 2.5\% charcoal stripped serum (SigmaAldri(h)

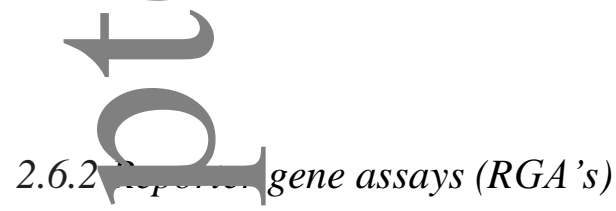

Four repo er gene cell lines were previously developed by transforming human mammary gland cell lines with the luciferase gene under the control of a steroid hormone inducible promotur as described in Willemsen et al ${ }^{26}$. The TARM-Luc cell line is specific for the detection androgens and progestagens, MMV-Luc cell line for oestrogens, TM-Luc for progestage's and TGRM-Luc for glucocorticoids and progestogens ${ }^{27}$. These transformed cell lim were routinely cultured in cell culture medium containing DMEM and $10 \%$ foetal bovine serum. DMEM without phenol red was used when culturing the MMV-Luc cell line. RGA's were carried out in assay media composed of DMEM and 10\% hormone depleted serum as previously described by Frizzell et al. ${ }^{28}$. Briefly, cells were seeded at a concentration of $4 \times 10^{5}$ cells $/ \mathrm{mL}, 100 \mu \mathrm{L} /$ well into white walled, clear and flat bottomed 96- 
well plates (Greiner, Bio-One, Frickenhausen, Germany) and incubated for 24 hours at $37^{\circ} \mathrm{C}$ with $5 \% \mathrm{CO}_{2}$ and $95 \%$ humidity.

After 24 hours, bDtBPP and the relevant steroid hormone standards dissolved in DMSO was added to the cells at a final DMSO concentration of $0.1 \%$. The final concentrations of bDtBPP during cell exposure was $0.005,0.025,0.035,0.05,0.1$ and $0.25 \mu \mathrm{g} / \mathrm{mL}$. The positive controls were: $1.36 \mathrm{ng} / \mathrm{mL}$ 17b-estradiol (MMV-Luc), $14.5 \mathrm{ng} / \mathrm{ml}$ testosterone (TARM-Luc), $157 \mathrm{ng} / \mathrm{mL}$ progesterone (TM-Luc) and $181 \mathrm{ng} / \mathrm{mL}$ cortisol (TGRM-Luc). A solvent co trol was also included for each cell line (0.1\% v:v DMSO in media). Antagonist te arried out by incubating bDtBPP $(0.005,0.025,0.035,0.05,0.1$ and $0.25 \mu \mathrm{g} / \mathrm{mL})$ with ne re evant positive control for the cell line being tested. The cells were incubated for $48 \mathrm{~h}$, the supernatant discarded and the cells washed once with $200 \mu \mathrm{l}$ PBS. The cells were lysed by addding $25 \mu \mathrm{L}$ cell lysis buffer (Promega, Southampton, UK) to each well. Finally, 100 y luciferase substrate (Promega, Southampton, UK) was injected into each well. Luciferase activity was measured using a Mithras Multimode Reader (Berthold, Other, Germo and the response compared to that of the solvent and positive controls. RGAs were performed in triplicate for each experimental point and in three independent exposures. The MTT cell viability assay was also performed on the treated RGA cells in parallel to this

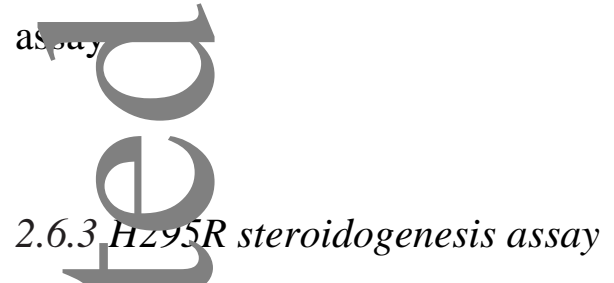

The H295R cell line was obtained from the American Type Culture Collection LGC Stana ards. The assay was carried out as described previously ${ }^{29}$. Briefly, the H295R cells were eảed at a concentration of $3 \times 10^{5}$ cells $/ \mathrm{mL}, 1 \mathrm{~mL} /$ well, into 24-well cell culture plates (BD E rences, Bedford, MA, USA). The cells were allowed to attach for 24 hours. Following ell attachment, the media was replaced with fresh H295R assay media containing the tect compounds (bDtBPP 0.005, 0.025, 0.035, 0.05, 0.1 and $0.25 \mu \mathrm{g} / \mathrm{mL}$ ) dissolved in DMSO a final concentration of $0.1 \%(\mathrm{v}: \mathrm{v})$. Forskolin $10 \mu \mathrm{M}$ (FSK10) was used as a positive ptrol and $0.1 \%$, v: v DMSO in media as a solvent control in triplicate. Forskolin has been shown to act as general inducer of steroidogenesis in the H295R cell line via activation of cAMP pathways, resulting in elevated levels of oestradiol, testosterone and progesterone ${ }^{29}$. After 48 hours of exposure, media was collected from each well and stored at $-20^{\circ} \mathrm{C}$ until hormone quantification was carried out using highly specific ELISAs as outlined 
previously ${ }^{27}$. All experimental points in the H295R assay were performed in triplicate and repeated in three independent exposures. The AlamarBlue ${ }^{\circledR}$ cell viability assay was performed on the cells remaining in each well.

\subsubsection{Hormone detection and quantification}

The steroid hormones oestradiol, testosterone, progesterone and cortisol levels in the media were quantified in duplicate by highly specific ELISA assays (DRG Diagnostics, Marburg, Germany). These highly specific kits are based on the principle of competitive binding and are intend $\mathrm{d}$ for the quantitative in vitro diagnostic measurement of oestradiol (0-2000 p tosterone $(0-16 \mathrm{ng} / \mathrm{mL})$, progesterone $(0-40 \mathrm{ng} / \mathrm{mL})$ and cortisol $(0-800 \mathrm{ng} / \mathrm{mL})$, with fensi vities of $10.60 \mathrm{pg} / \mathrm{mL}, 0.083 \mathrm{ng} / \mathrm{mL}, 0.045 \mathrm{ng} / \mathrm{mL}$ and $2.5 \mathrm{ng} / \mathrm{mL}$ respectively (DRG Dlagnostics, 2016; DRG Diagnostics, 2009; DRG Diagnostics, 2007; DRG Diagnostics, 2006). In order to assess their suitability for measuring the steroid hormones, oestradiol, testosterone, progesterone and cortisol standard curves were prepared in H295R cell caltures. The ELISA was validated for measuring the steroid hormones in this culture mediun All other steps in the ELISAs were carried out in accordance with the manuraturer's instructions (DRG Diagnostics, 2016; DRG Diagnostics, 2009; DRG Diagnostics, 2007; DRG Diagnostics, 2006). The intra-assay coefficients of variation were le $\%$. Each ELISA plate contained a standard curve, solvent control, positive control and thu compound bDtBPP concentrations. The optical density was measured at $450 \mathrm{~nm}$ wave iength using a Sunrise spectrophotometer (TECAN, Switzerland). The mean absorbance obtained from each standard was plotted against its concentration using dose-response curves generatod with GraphPad PRISM 5 software.

2.6.5 (C) iability assays

As well a visual inspection of the RGA and H295R cells under the microscope to evaluate cell r.orph logy and attachment, cell viability assays were performed in parallel to the assays to checn lor any toxic effects of the concentrations of bDtBPP which the various cell lines were posed to. For the H295R and RGA cell lines, the AlamarBlue ${ }^{\circledR}$ assay ${ }^{30}$ and MTT assay respectively, was carried out as reported previously.

2.6.6 Statistical analysis 
All experimental points in the H295R assay, RGAs and cell viability assays were performed in triplicate and repeated in three independent exposures. All values shown are expressed as mean \pm standard error of the mean of the three independent exposures $(n=3)$. Data were analysed using Microsoft Excel and Graphpad PRISM 5.01 software. A one way analysis of variance (ANOVA) and Dunnett's Multiple Comparison Test was used to determine significant differences between the treatments and the corresponding controls. The mean concentrations were tested for significant difference at the $95 \%$ confidence level. The criter on fo significance was considered as $p$-value of $\leq 0.05, p=\leq 0.05(*) \leq 0.01 \quad(* *) \leq 0.001$ $(* * *)$.

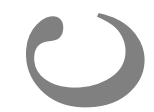

27 Motahlic profiling using the SeaHorse Agilent Seahorse XF-96 extracellular Flux Analisor)

Oxyg-ansumption rate (OCR) and extracellular acidification rate (ECAR) were measured using th ell metabolic analyser Seahorse XF96 (Agilent technologies) according to the manufar turer's instructions. $2 \times 10^{5}$ cells were cultured in $5 \mathrm{~mL}$ of media conditioned in $\mathrm{F}-1$, F-2 and Control glass bottles and cultured for 96 hours at $37{ }^{\circ} \mathrm{C}$. A Seahorse XF96 cell culturo nldte was previously coated with Corning Cell-Tak cell and tissue adhesive (Corninots, $22.4 \mu \mathrm{g} / \mathrm{mL}$ ) and incubated for 1 hour in a $37{ }^{\circ} \mathrm{C}$ non- $\mathrm{CO}_{2}$ incubator. Cond rone 1 media were replaced by unbuffered Seahorse XF media for Phenotype assays and witn Buffered Seahorse XF media (without phenol red) for glycolytic rate assays. In both cases, Seahorse XF media were supplemented with $10 \mathrm{mM}$ glucose, $1 \mathrm{mM}$ pyruvate and 2

$\mathrm{mM}$ grutamm and $\mathrm{pH}$ adjusted to 7.4. Finally, $2 \times 10$ ? viable cells/well were pelleted, re-

suspended in the corresponding Seahorse XF media and plated into the previously coated plate (50uL containing 400 cells/ $\mu \mathrm{L}$ per well, 2 x 10 ? viable cells/well). Plates were centrif. culat $300 \mathrm{~g}$ for 1 minute, incubated at $37{ }^{\circ} \mathrm{C}$ in a $\mathrm{CO}_{2}$-free incubator for $30 \mathrm{~min}$ and $150 \mu \mathrm{s}$ of , Seahorse media were carefully added to each well, followed by a 30 minute incubation. Three real-time measurements of OCR and ECAR were directly measured (basal readings) and after injection of different mitochondrial inhibitors or glycolytic modulators. For phenotypic assays, the cells were treated with optimized concentrations of oligomycin (1 $\mu \mathrm{M})$, carbonyl cyanide p-[trifluoro-methoxy]-phenyl-hydrazone (FCCP; $1 \mu \mathrm{M})$. For the 
$\mathrm{d}$ with optimized concentration of rotenone + Antimycin $\mathrm{A}(0.5 \mu \mathrm{M})$ and 2-deoxy-D-glucose (50 mM). Oligomycin, FCCP,

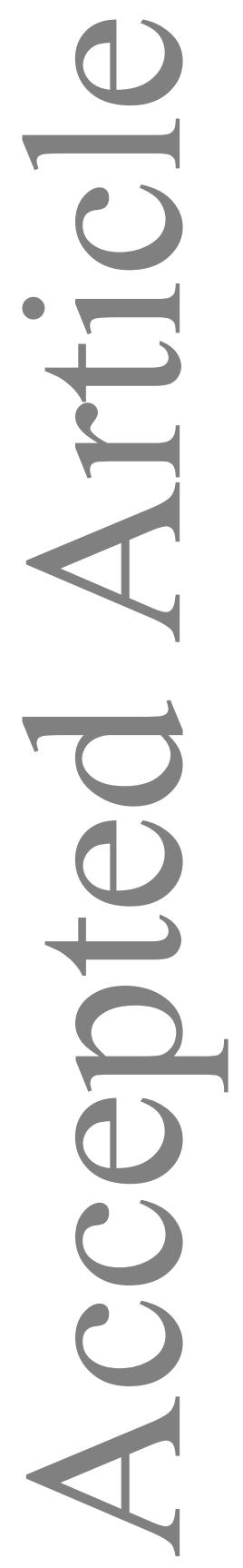


rotenone + antimycin A and 2-deoxy-D-glucose concentrations were optimized according to the manufacturer's instructions. The corresponding assay, phenotype assay or glycolytic rate assay were run using the Seahorse XF-96 analyser pre-programmed templates for these assays.

\subsection{Quanti tive Label-free LC-MS/MS Proteomic Analysis}

Cit purts from the CHO-K1 and CHO-DP12 cell lines treated with BalanCD ${ }^{\circledR}$ Growth A medi $A$ con itioned in both F-1 and F-2 films for 7 days as well as negative control media were lysed in a buffer containing $7 \mathrm{M}$ urea, 2M Thiourea, 4\% CHAPS and $30 \mathrm{mM}$ Tris at $\mathrm{pH}$ 8.5. Proteir concentration was determined using a QuickStart Bradford protein assay (Biorad) and $190 \mu \mathrm{g}$, of each sample was prepared for quantitative proteomic analysis. Protein samples were prepared as previously described using the Filter Aided Sample Prep (FASP) method and $C_{2}$ peptide purification ${ }^{32,33}$. Nano LC-MS/MS was performed using a Dionex Ultimate 3000 nanoRSLC (Thermo Scientific) coupled in-line to an Orbitrap Fusion Tribrid mass spectrometer (Thermo Scientific). LC-MS/MS methods were applied as previously described ${ }^{34}$ rryolem dentification was achieved using Proteome Discoverer 2.2 with Sequest HT and MASC 1 algorithms. Data was searched against the NCBI Chinese Hamster Ovary (Cricetulu griseus) protein database downloaded in November 2017 containing 24,906 sequences)Quantitative label-free data analysis was performed using Progenesis QI for Prote (version 2.0, Nonlinear Dynamics, Waters) essentially as described by the manu Protein identifications from Proteome Discoverer were imported into Prog nesis QI for Proteomics for differentially expressed proteins. Proteins were considered differentially expressed if they passed the following criteria (i) a minimum of 2 peptides contributiv to a protein identification (ii) an ANOVA $p$-value score $<0.05$ between sample sets and (ii ) a minimum of 1.5-fold change in abundance between sample sets. 


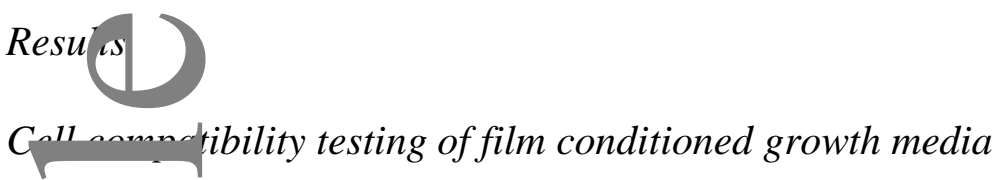

We perfor led biocompatibility profiling of two films sourced from the same vendor; one of which was an older film (F-1) and one a more modern film (F-2) of the same design. To asses s the jotential cellular toxicity of leachable compounds derived from newly developed mate (als as opposed to single molecule screening, as in the case bDtBPP ${ }^{15}$, we conditioned chemically defined media using SUBs made of the two referred films, F-1 and F-2. The co all of other leachates and the array of concentrations that each compound accumulates, could all $\mathrm{P}$ ay a role in toxicity. These two films were chosen to determine, in an extreme case of a poor performing SUB versus a good performing SUB, what the influence to CHO cell calture was.

In ke - jing with our previous study ${ }^{15}$, both the parental $\mathrm{CHO}-\mathrm{K} 1$ and the monoclonal antibouy (mAb)-producing CHO-DP12 cell lines were evaluated for compatibility with both film-conditioned media. Culture media was conditioned in both F-1 and F-2 films over a 7 day t me course to capture the full complement of potential plastic sub-components to leach into the culture media and to do so at concentrations most likely to elicit toxic effects. Follown on from this, the same basal culture media was carried through an identical cond conir o process in both F-1 and F-2 films for a 3 day time course. This more modest condition ing time was selected to reflect both previously published conditioning timelines ${ }^{14}$ as well as determine the potential toxicity to cultures in the immediate stages of culture.

CHO cells cultured in media conditioned for 7 days in the F-1 film demonstrated consiauably reduced growth when compared to control cultures (Fig. 1A). This growth inhibitory F-1 media did not appear to negatively impact $\mathrm{CHO}$ cell viability (Fig. 1B). In contrast, $\mathrm{CHO}-\mathrm{K} 1$ cells cultured in F-2 film conditioned media exhibited no adverse growth effects when compared to controls (Fig. 1C and D). Similarly, when the mAb-producing 
CHO-DP12 cell line was subjected to the same 7 day conditioned media, the F-1 film was observed to reduce cell growth with no deleterious effects on culture viability when compared to controls (Fig. 1E and F). A $\sim 60 \%$ reduction in mAb production (Fig. 1G) was observed in the case of F-1 cultured CHO-DP12 cells. As in the case of CHO-K1s, CHODP12 cells cultured in the F-2 conditioned media behaved similar to the controls while maintaining similar antibody productivity when cultured in the 7-day conditioned media (Fig. 1 H-J).

We next nerated conditioned media using both F-1 and F-2 films for a time course of 3 $\mathrm{d}_{i}, \mathrm{Crr} / \mathrm{K} 1$ cells cultured in conditioned media from both F-1 and F-2 films demonstrated comparably growth and viability to control media (Fig. 2A-D). In the case of CHO-DP12 cells, cen growth, viability and productivity remained similar to that of controls for both F-1 (Fig. 2E-G) and F-2 (Fig. 2H-J) films.

\section{Label-fr C-MS/MS profiling of the toxic versus compatible films}

From tho cll toxicity data, it is evident that conditioned media generated from the F-1 film over a 7-day time course is inhibitory to $\mathrm{CHO}$ cell growth and productivity when compared tora nore nodern film conditioned for the same time. For this reason, we performed labelfree LC-IVIS/MS proteomic profiling on CHO-K1 and CHO-DP12 cells cultured in both films cond tione for 7 days only.

Labe,-IEe LC-MS/MS on CHO-DP12 and CHO-K1 cells cultured in the toxic F-1 cond (oned media and sampled after 96 hours revealed 155 differentially expressed (DE) proteins in both CHO-DP12 and CHO-K1 cells (Sup. Table 1) with 35 common across both cell lines ig. 3A). Qualitatively, 4667 and 5092 proteins were identified in CHO-DP12 and CHO K1 dells, respectively (Sup. Table 2), cultured in F-1 conditioned media with Table 1 showing a subset of the common DE proteins between both cell types.

One ilmusting group of proteins that were down-regulated in both CHO-DP12 and CHO-K1 cells posed to F-1 film conditioned media were all components of the NADH dehyaregenase enzyme (Complex I), NDUFS2, NDUFS8, NDUFV1, and NDUFA10 of the mitochondrial electron transport system (ETS). Given this observation, we assessed mitochondrial function through the measurement of oxygen consumption rate (ECR) using a micro-plate based measurement (Seahorse Bioscience XF Analyzer). The rate of oxygen 
consumption was reduced in $\mathrm{CHO}$ cells cultured in F-1 conditioned media where as normal mitochondrial activity was observed in cells cultured in F-2 conditioned media when compared to negative controls (Fig. 3B). When extracellular acidification rate (ECAR) of the culture media was determined, it was observed that slow growing $\mathrm{CHO}$ cultures from $\mathrm{F}-1$ conditioned media exhibited a reduced rate of extracellular media acidification when compared to F-2 conditioned media and negative controls (Fig. 3C). Gene-Ontology analysis based on DE proteins in CHO-K1 and CHO-DP12 cells cultured in F-1 film conditioned medi $r$ rev aled the enrichment for biological processes relating to oxidative stress and mitochondrial respiratory chain complexes (Table 2). Up-regulation of the mitochondrial Lon Protease (LONP1) was identified in F-1 cultured $\mathrm{CHO}$ cells which is a protein responsib 1 for responding to acute oxidative stress ${ }^{35}$.

When CHO-DP12 and CHO-K1 cells cultured in the non-toxic F-2 film conditioned media and subjected to proteomic analysis, it was interesting to observe 108 and 268 proteins DE in CHOrDr1 and CHO-K1 cells, respectively (Sup. Table 3). There were 19 DE proteins comm to both cell types with two proteins demonstrating contrary expression patterns, glutatmine synthetase and coatomer subunit alpha. When compared to the 35 common DE proteins from cells cultured in the toxic F-1 conditioned media (Table 1), there was 1 protein fo protem IFCR), (Fig. 3A). However, although this common DE protein was found to be decreased $\rightarrow$ its expression in cells cultured in the toxic F-1 conditioned media, it was highest in its abundance in CHO-DP12 and CHO-K1 cells cultured in F-2 conditioned media. It is apparent from this study that media conditioned from a SUB film (F-2) that does not impact on Cun ell growth does still influence the cells proteome. It is not surprising that differ atial protein expression was observed for both films as leachables were present in both cases as une following analysis will demonstrate.

\section{Leachal profiling of conditioned media}

Sixte cornpounds with confirmed and confident identification from the media extracts by LC-MS are listed in Table 3. Twelve of the 16 compounds (75\%) were present at higher levels in F-1 bags compared to F-2 (Fig. 4A), including 2 degradation products of Irgafos ${ }^{\circledR} 168$ : bDtBPP, which has negative effects on CHO cells, as indicated in previous sections, and Irgafos ${ }^{\circledR} 168$ oxidized form. The non-volatile compounds N,N-dimethyldecan- 
1-amine $\left(\mathrm{C}_{12} \mathrm{H}_{27} \mathrm{~N}\right)$ and cis-1,3-docosenic acid amide (Kemamide ${ }^{\circledR} \mathrm{E}$ ultra) $\left(\mathrm{C}_{22} \mathrm{H}_{43} \mathrm{NO}\right)$ were detected only in F-2 bags. Figure 4B and $\mathbf{C}$ shows LC chromatograms for F-1 and F-2 extracts, where some leachables with higher concentrations in F-1 are highlighted, including bDtBPP as mentioned previously.

In general terms, the identified non-volatile compounds belong to different chemical classes and also perform different functions as components of plastic materials. Major extractable compounds identified can be classified as antioxidants and their degradation products, plasticiser polymer-related compounds, as degradation products and building blocks, and renidun folm the polymerisation process, such as initiators and catalysts. The groups of compoună with specific functions that were identified in the samples are also reported in Table J. Several of these compounds were already reported previously ${ }^{36-38}$. Intact Irgafos ${ }^{\circledR} 168$ was not detected under any extraction condition.

The dentifjed compounds were also structurally classified via Toxtree version 2.6.0 ${ }^{39}$ using the Cramer rules with extensions. Based on quantitative structure-activity relationships $\left(\mathrm{Q}^{\mathrm{C}} \mathrm{K}\right)$, the Cramer classification is a rules-based process that sorts compounds into three classes; $\mathrm{CH}_{\mathrm{H}}$ ss 1 (low risk of toxicity), Class 2 (intermediate between 1 and 3), and Class 3 (either no basis to presume safety or suggest significant toxicity). Additionally, the entire popuation of compounds was assessed by in silico QSAR analysis for their mutagenic/carcinogenic potential using the Benigni/Bossa rule base. The Cramer classificat ${ }^{*}$ ns and mutagenicity assessments were performed using the appropriate modules of software. Results indicated that most leachables $(75 \%)$ are quite toxic, being class ad Cramer Class 3 and only 25\% were in Cramer Class 1. But nevertheless only 2 compoumus (13\%) triggered an in silico alert for mutagenicity, which also belong to Cramer Class (1. T he referred compounds, 2,(4 or 6)-toluendiamine and 2,4-dimethyl-aniline, are residyes from the polymerization process, and have presumably the highest safety risks of the group. ationally, these compounds are also at higher levels in F-1 bags compared to F-2.

Regardine clemental analysis, only 9 elements of 30 were found in the samples (Table 3). As shown in igure 4D, 4 of the 9 elements (44\%): $\mathrm{Ni}, \mathrm{Ag}, \mathrm{Sn}$, and $\mathrm{Ba}$ were at higher convent ations in F-1 bags, and the other 5 elements (56\%): V, Mo, Cd, and Pb, showed the highest levels in F-2 bags, while Cu levels were similar in both SUBs. V and Cd were found only in F-2 bags, while Ba was only found in F-1 bags. The ICH Q3D guidelines ${ }^{40}$ classify elements in three classes based on their toxicity and likelihood of occurrence in the drug 
product, and also specify both daily doses and concentration limits of metallic impurities in pharmaceutical final products and in active pharmaceutical ingredients and excipients. According to these guidelines, the highest levels of $\mathrm{Pb}$ and $\mathrm{Cd}$, Class 1 elements and the most toxic ones were found in F-2 films, followed by Mo and V that belong to Class 2A. Ag, also a toxic element (Class 2B) is the only element of concern that was found at higher concentrations in F-1 films (Fig. 4E and Table 3).

Interestingly, when a subset of metal ions $(\mathrm{Ag}, \mathrm{Pb}$ and $\mathrm{Ni}$ ) were screened in $\mathrm{CHO}-\mathrm{K} 1$ and CHODP1 cells at a high concentration of $1 \mathrm{mg} / \mathrm{L}$, similar to previous screening studies ${ }^{13,15}$, A Ind to be the only metal to elicit toxic effects on growth of both CHO-K1 and CHODPI) cells (Fig. 5A and C). Silver (Ag), previously categorised as a toxic element (Class 2B) was observed to be at a higher abundance in F-1 films than F-2 films (Fig. 4D). However, when lower concentrations of $\mathrm{Ag}$ were screened, the toxicity effects impacting $\mathrm{CHO}$ cell growth and productivity, in the case of the CHO-DP12s, was not apparent (Fig. 5B, $\mathbf{D}$ and $\mathbf{E}$ ). Surprisingly, $\mathrm{Pb}$ (lead), despite being classed as Class 1 and highly toxic did not exhibit aly negative effects on $\mathrm{CHO}$ cell growth and viability when screened at $1 \mathrm{mg} / \mathrm{L}$ and appeard to be higher in abundance in the non-toxic F-2 film compared to the F-1 film (Fig. 5A and B). As concentration levels and the thresholds of toxicity would play a role in af and growth, further investigation is needed to determine whether metals such as silver ibuted to the toxicity of the F-1 conditioned media as well as determining the exac(neta species present within the conditioned media as opposed to the metal salt used during toxisity screening.

\section{$b D t B P P$ endocrine disruption potential testing in vitro}

Lastly leachable compounds from plastic materials have long been on the radar in relation to their afet profiles to human health such as bisphenol A ${ }^{41}$. Not only in the context of their poter nal to xicity to the bioprocess itself, leachables from the final container closure system, packaging components such as pre-filled syringes and/or processing equipment also pose a thres of the patient ${ }^{42}$ if present in the active biopharmaceutical ingredient. Using H295R cells, a range of concentrations of bDtBPP previously observed to negatively impact $\mathrm{CHO}$ cell growth ${ }^{15}, 0.005-0.25 \mu \mathrm{g} / \mathrm{mL}$, was tested in relation to its capacity to disturb hormone production or interact with a range of hormonal receptors. The production of a range of hormones, testosterone, progesterone, estradiol and cortisol was not observed to be induced 
or retarded by incubation with various concentrations of bDtBPP (Sup. Fig. 1). No agonsim was observed in the estrogen, androgen, glucocorticoid and progesterone receptors when tested by reporter gene assays (RGA). However, when bDtBPP was screened by coincubation with various hormones, testosterone, estrogen, progesterone and cortisol, it was observed that between $0.1-0.25 \mu \mathrm{g} / \mathrm{mL}$ of bDtBPP acts as an androgen antagonist (Fig. 6B), thereby inhibiting the natural association of testosterone with its endogenous receptor.

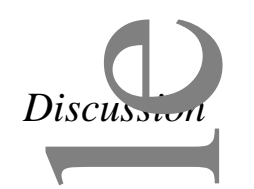

Shortly before the discovery of bDtBPP, a means of testing newly developed films for cell cultur npatibility was published by Genentech, which monitored the growth of cells in mediat that had been stored in 13 different single-use bags ${ }^{43}$. This study highlighted 4 viable bag IIIII options, however, concluded that a "volatile or air-quenched compound, likely genei y gamma irradiation of the problematic bag film" to be the source of their poor perform e in cell-based assays. Recently, Dorival-García et al., reported a novel solvent systom for the optimised study of highly hydrophobic compounds of which bDtBPP falls under for the identification of potentially non-satisfactory films for cultivation of CHO cell lipes 44 Oritically, these studies were performed under realistic possible conditions and deternine he milieu of leachables from SUBs that enter the growth media and potentially cause ( th eat to cell growth. In this instance, in the absence of a benchmark for a "good" performmg bag, cell culture media were conditioned by incubation at $37^{\circ} \mathrm{C}$ in two $\mathrm{SUBs}$ made with different plastic films as a means to capture the full leachable profile derived from each film Inder normal processing conditions and compared to the corresponding control using las bottles. Two conditioning times were selected in advance; a 7 day time course to best ane the cocktail of leachables derived from these two films in excessive conc ntrat ins and; a 3 day time course to capture leachable content over a more modest culture tıme period.

It was evident that cell culture media conditioned in the older film (F-1) was toxic to CHO cell ${ }^{\mathrm{vth}}$ with a negative impact on IgG productivity when incubated for 7 days prior to inoculation This level of toxicity was not observed in the case of media conditioned in the more modern F-2 film for the same 7-day incubation with cultures performing similar to negative controls and fresh media controls. This suggests that changes have been made in the composition of the plastic materials going from F-1 to F-2 bag generations. Based on 
reported data, the pre-requisite secondary anti-oxidant, Irgafos ${ }^{\circledR} 168$, is the origin of the known toxic leachable bDtBPP upon gamma irradiation ${ }^{45}$. Eliminating $\operatorname{Irgafos}^{\circledR} 168$ as a material component during the extrusion process (e.g. high temperature, shear etc.) can dramatically affect polymer degradation ${ }^{46}$. However, minimizing the concentration of Irgafos $^{\circledR} 168$ and thereby the amount of bDtBPP that can leach has been a proposed alternative for film development and process control ${ }^{47}$, which is the case in these two films going from F-1 to F-2. Leachable testing of both F-1 and F-2 film extracts demonstrated that the 1 athat bDtBPP was present at far higher concentrations in the F-1 condition media comparea to the more recent F-2 film (Fig. 4B and C), potentially contributing to the cellular toxicity observed in the case of $\mathrm{F}-1$ cultured $\mathrm{CHO}$ cells. In relation to the abundance of its pre-requisi Irgafos ${ }^{\circledR} 168$, this was not detected under any extraction conditions preventing uo fr ncluding that reduced bDtBPP is a result of minimal Irgafos ${ }^{\circledR} 168$ content. Evid/lno d ggests that it may be degraded during the incubation step due to oxidation at high temporature and the use of polar extraction solvents ${ }^{48-50}$.

Previou ndies have demonstrated bDtBPP to leach at concentrations ranging from 0.025 $0.11 \mathrm{mo} / \mathrm{L}$ in a panel of SUB films over a 4 day conditioning period ${ }^{14}$. Our data indicates that a residency time period of 3 days may not be sufficient enough to leach toxic compounds 作 DP12 call exposed to the toxic F-1 7 day conditioned media revealed several biological processes r ritical to bioprocess efficiency (Table 1). Reduced growth of both CHO cell lines in $\mathrm{F}_{1} \mathrm{l}$ conditioned media exhibited a weakened capacity for ATP synthesis through diminished electron transport through the mitochondrial electron transport system as well as an in reased response to oxidative stress. Gene ontology analysis of the DE proteins in both $\mathrm{CHO} 1$ and $\mathrm{CHO}-\mathrm{DP} 12$ cells cultured in F-1 conditioned media supported this observation with anment for biological processes associated with oxidative stress and oxidative phosphory tion (Table 2). This weakened mitochondrial activity was highlighted through the reduction in expression of a subset of proteins all involved in NADH dehydrogenase activily DUFS2, NDUFS8, NDUFV1 and NDUFA10) ${ }^{51}$. This complex, composed of 47 sub-unit mtDNA encoded/40 nDNA encoded), represents the main electron entry point of the ETS as well as contributing substantially to the formation of the proton gradient across the inner mitochondrial membrane, which drives ATP synthesis culminating in the consumption of oxygen and the generation of water ${ }^{51}$. Interrogating this phenotype further determined that the oxygen consumption rate (OCR) of cells cultured in F-1 conditioned 
media displayed a reduced OCR when compared to negative controls and cells cultured in the non-toxic F-2 conditioned media. Previous studies have demonstrated that $\mathrm{CHO}$ cells under a med-high fed-batch culture process exhibited a reduce OCR in combination with a fastgrowing phenotype when compare to controls ${ }^{52}$. Furthermore, the extracellular acidification rate (ECAR) was also found to be reduced in F-1 cultured cells exhibiting impeded growth capacity when compared to F-2 cultured cells and negative controls (Fig. 3C). Acidification of the culture media is a result of lactate production through glycolytic metabolism and is a meta 0 olic 1 athway associated with biomass accumulation and exponential cell growth ${ }^{52}$.

C 11 contr $\Omega$ cell's suggesting that the underlying cellular architecture (19 DE proteins common to both Crr-K1 and CHO-DP12s) that is influenced by the potential leachates derived from the F-2 film does not impact critical biological processes. Oxidative stress was another signature biological process evident in F-1 conditioned media-exposed cells with proteins such as LONAT and VNN1 being increased in abundance. Previous spiking studies using bDtBPP alone raled oxidative stress through the expression of heme oxygenase 1 (HMOXI) further supporing the presence of this leachate in F-1 film conditioned media ${ }^{15}$, as shown by LCMS. The mechanism of action of bDtBPP negatively impacting $\mathrm{CHO}$ cell cultures is ther than what is indicated through proteomic profiling. However, the chemical comp ... n of bDtBPP itself gives this molecule potentially a high affinity for oxygen there ofe s avenging dissolved oxygen within the media resulting in hypoxia, a biological process further highlighted in previous work through the expression of hypoxia upregulated protein 1 (HYOU1). A simple spiking study of bDtBPP versus a DMSO control in media resulted in ar accelerated depletion of dissolved oxygen when monitored using the Oxyg aph-?k respirometer (Data not shown), indicating the potential for this leachable and by assonration the F-1 conditioned media to induce hypoxia in cultured cells.

Leachu. analysis further highlighted a panel of compounds present at higher concentrati $n$ ns in the F-1 film compared to F-2 film extracts again suggesting reduced primary rav materials used in bag manufacturing such as in the case of $\operatorname{Irgafos}^{\circledR} 168$ as ind ate by the reduced concentration of bDtBPP (Fig. 3B and C). From a panel of trace metals scruened, silver (Ag) was the only one found to be toxic to both $\mathrm{CHO}-\mathrm{K} 1$ and $\mathrm{CHO}-$ DP12 cells at high concentrations of $1 \mathrm{mg} / \mathrm{L}$. Despite its toxicity at such high concentrations, silver elicited no growth inhibitory effects at doses as high as $0.25 \mathrm{mg} / \mathrm{L}$ (Fig. 5A and C). Going from generation F-1 to generation F-2, the levels of Ag within film extracts are 
reduced but still present (Fig. 4D). The poor performance of $\mathrm{CHO}$ cells when cultured in F-1 conditioned media could be as a result of the combined effects of toxic leachates such as $\mathrm{bDtBPP}$ and $\mathrm{Ag}$, however, further investigation would be required to examine the exact concentrations of leachables that enter the media after 7 days and if these concentrations are in line with cell toxicity assays. It is also important to note that the metal salts used in this screen may not reflect the exact metal species that leaches from these plastic films but remains indicative of potential toxicity with further investigation being require.

Validatino he safety profile of the F-2 film over its predecessor F-1 counterpart for CHO cell cr an important step forward in progressing the adoption of this technology for recor Jina t protein drug manufacturing within the biopharmaceutical industry. However, from the perspective of human health, most plastic products release estrogenic chemicals ${ }^{41}$ highlighting the potential for endocrine disrupting leachates to be present within the media and pssibly persisting through purification processes. We have demonstrated that the wellknown leachate, bDtBPP, is considerably reduced in its abundance in the more recent film genern (F-2) but is still present. Using this as an example, it was evident upon screening at a ra.ge of concentrations $(0.005-0.25 \mathrm{mg} / \mathrm{L})$, as previously reported ${ }^{15}$, that bDtBPP possessed the capacity to act as an androgen receptor antagonist (Fig. 6B). It has previously b . . . J ed that bDtBPP accumulates to levels ranging from $0.025-0.11 \mathrm{mg} / \mathrm{L}$ over 3-4 days oation under bioprocess-relevant conditions ${ }^{14}$. Our data demonstrates that this leachate py sent in modern generations of films can potentially act as an endocrine disruptor at concentrations reported to leach and accumulate in media extracts. Leachable analysis in this procant study was qualitative, allowing for normalised abundances between F-1 and F-2 films and of exact concentrations. Regardless, the potential for additional leachables from SUB $r$ si gle-use technologies requires further investigation.

\section{Conclusien}

Single-use technologies, in particular SUBs, are gaining wide-spread acceptance within the biom facturing space due to more recent generations of films being developed and a better understanding on the safety concerns around leachable materials. We have demonstrated that media conditioned in an older F-1 SUB film inhibited cell growth when compared to controls. Contrary to this, cells cultured in media conditioned using a newer film generation, F-2, reached similar cell densities to control cultures. Poor cell growth was associated with 
reduced mitochondrial activity as well as glycolytic metabolism in addition to oxidative stress, highlighted through proteomic analysis. Parallel leachable analysis on film extracts used for cell culture assays demonstrated that the abundance of most leachates was reduced when going from one generation to the next including the toxic compound bDtBPP as well as the potentially toxic metal silver (Ag). Other compounds were identified that were unique to the more recent film generation (F-2) which suggests that new material components are being used in film manufacturing and therefore must be subjected to $\mathrm{E} \& \mathrm{~L}$ analysis as well as toxic olpgy screening. As the pre-requisite component of bDtBPP, Irgafos ${ }^{\circledR} 168$, was not detected in either F-1 or F-2 extracts, we were unable to definitively conclude that the reduced levels of bDtBPP leaching was due to reduced Irgafos ${ }^{\circledR} 168$ starting material. Furtherm $e$, in the case of the toxic F-1 film, there appears to be a time-dependency which anow reanhables to accumulate to toxic levels in the case of 7 versus 3-day conditioning stuat runs anch is 48-72 hour seed trains used in scale-up without compromising cell growth whereas 1o iger fed-batch production processes may be more suited to newer films. Finally, aftu evaluating the safety profile of a modern single-use film for CHO cell culture, we demonstrated that leachables such as the well-known bDtBPP possess the capacity to act as an endocrine disruptor, in particular, an androgen antagonist. This would suggest that further studies sho ld be performed to know, in more detail, the effects such leachates have on the endoc ne system and the potential threat to patient safety. Studies such as this support the safe in mentation of SUBs within the biopharmaceutical industry and demonstrate that bag mantracturers are tailoring plastic formulations to address past concerns over toxic leach ibles. Nevertheless, the lack of standardisation and regulation emphasises the necessity to further develop a toolkit for assessing the safety and biocompatibility of emerging films for use inbior anufacturing.

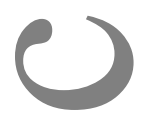

\section{Ackn fwled ements}

This wo was supported by funding from Science Foundation Ireland (SFI) Grant number 13/SRSS PC/12893. The Orbitrap Fusion Tribrid mass spectrometer was funded under an SFI Infrastructure Award to Dublin City University, grant number 16/RI/3701. The authors would also like to acknowledge the contribution of the Irish Industry Technical Group (Allergan Pharmaceuticals Ireland, BioMarin Manufacturing Ireland Ltd., Eli Lilly and Company, 
Genzyme Ireland Ltd. A Sanofi Company, Janssen Biologics, MSD and Pfizer Ireland Pharmaceuticals) throughout this work.

\section{Conflicts of Interest}

The authors declare no commercial or financial conflict of interest.

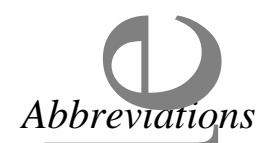

bDtBPP - bis(2,4-di-tert-butylphenyl)-phosphate, CHO - Chinese hamster ovary, DE Diffeenti ly Expressed, E\&Ls - Extractables and Leachables, mAb - Monoclonal antibody, PEG

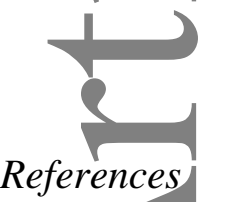

1. Shukla AA, Gottschalk U. Single-use disposable technologies for biopharmaceutical Imanylfacturing. Trends Biotechnol. 2013;31(3):147-154. doi:10.1016/j.tibtech.2012.10.004.

2 D n 'G, Moreira A, Brorson K. Disposable bioprocessing: The future has arrived. Biot chnol Bioeng. 2009;102(2):348-356. doi:10.1002/bit.22192.

3. $\quad$ ib1 R, Kaiser S, Lombriser R, Eibl D. Disposable bioreactors: The current state-ofthe $\mathrm{rt}$ and recommended applications in biotechnology. Appl Microbiol Biotechnol. 2010;86(1):41-49. doi:10.1007/s00253-009-2422-9.

4. Whitford WG, Pence BL. Impact of single-use technology on continuous bioplocessing. BMC Proc. 2013;7(Suppl 6):P39. doi:10.1186/1753-6561-7-S6-P39.

5. Butler M, Meneses-Acosta A. Recent advances in technology supporting biop larmaceutical production from mammalian cells. Appl Microbiol Biotechnol. LU12;96(4):885-894. doi:10.1007/s00253-012-4451-z.

6. Lan er ES, Rader RA. Single-use technologies in biopharmaceutical manufacturing: A 10-vear review of trends and the future. Eng Life Sci. 2014;14(3):238-243. doi: $0.1002 /$ elsc.201300090.

7. Kelly PS, Clarke C, Clynes M, Barron N. Bioprocess engineering: micromanaging -rilnese hamster ovary cell phenotypes Chi. Pharm Bioprocess. 2014;2(4):323-337. d bi:10.4155/PBP.14.28.

8. Sun T, Li C, Han L, Jiang H, Xie Y, Zhang B, Qian X, Lu H, Zhu J. Functional knockout of FUT8 in Chinese hamster ovary cells using CRISPR/Cas9 to produce a defucosylated antibody. Eng Life Sci. 2015;15(6):660-666.

doi:10.1002/elsc.201400218. 
9. Kallehauge TB, Li S, Pedersen LE, Ha TK, Ley D, Andersen MR, Kildegaard HF, Lee GM, Lewis NE. Ribosome profiling-guided depletion of an mRNA increases cell growth rate and protein secretion. Sci Rep. 2017;7(January):40388. doi:10.1038/srep40388.

10. Thaisuchat H, Baumann M, Pontiller J, Hesse F, Ernst W. Identification of a novel temperature sensitive promoter in CHO cells. BMC Biotechnol. 2011;11(1):51. doi:10.1186/1472-6750-11-51.

11. Kadarusman J, Bhatia R, McLaughlin J, Lin WLR. Growing cholesterol-dependent NSO myeloma cell line in the wave bioreactor system: Overcoming cholesterolToly mer interaction by using pretreated polymer or inert fluorinated ethylene vro ylene. Biotechnol Prog. 2005;21(4):1341-1346. doi:10.1021/bp050091+.

1. _ Lra . Kennedy JH, Ronk M, Marghitoiu L, Lee H, Nashed-Samuel Y. Ambient analysis of leachable compounds from single-use bioreactors with desorption elec iospray ionization time-of-flight mass spectrometry. Rapid Commun Mass Spectrom. 2014;28(21):2285-2291. doi:10.1002/rcm.7021.

13. Hammond M, Nunn H, Rogers G, Lee H, Marghitoiu A-L, Perez L, Nashed-Samuel Y, Anderson C, Vandiver M, Kline S. Identification of a leachable compound detrimental to cell growth in single-use bioprocess containers. PDA J Pharm Sci Technol.

2013,67(2):123-134. doi:10.5731/pdajpst.2013.00905.

14 ammond M, Marghitoiu L, Lee H, Perez L, Rogers G, Nashed-Samuel Y, Nunn H, $\mathrm{K}$ line S. A cytotoxic leachable compound from single-use bioprocess equipment that causes poor cell growth performance. Biotechnol Prog. 2014;30(2):332-337. doi:10.1002/btpr.1869.

15. Kelly PS, McSweeney S, Coleman O, Carillo S, Henry M, Chandran D, Kellett A, D. es J, Clynes M, Meleady P, Barron N. Process-relevant concentrations of the eachable bDtBPP impact negatively on $\mathrm{CHO}$ cell production characteristics. Bio chnol Prog. 2016;32(6):1547-1558. doi:10.1002/btpr.2345.

16. M: Teresa HS, Cindy Z, Satish SK. Impact of extractables/leachables from filters s stability of protein formulations. J Pharm Sci. 2011;100(11):4617-4630. doi:goi.org/10.1002/jps.22670.

17. Rainer B, Christian B, Klaus WB. Analysis of volatile radiolysis products in gammairrar ated LDPE and polypropylene films by thermal desorption-gas chromatographymass spectrometry. Appl Radiat Isot. 2000;52(2):251-269. doi:doi.org/10.1016/S0969804. (99)00125-6.

18. Andersson T, Nielsen T, Wessl??n B. Degradation of low density polyethylene during extr sion. III. Volatile compounds in extruded films creating off-flavor. J Appl Polym Sct. 2005;95(4):847-858. doi:10.1002/app.21278.

19. Corival-García N, Bones J. Evaluation of solvent systems for optimized extractables sudies of single use bioprocessing solutions. J Chromatogr A. 2017;1513:69-77. doi:10.1016/j.chroma.2017.06.066.

20. Dorival-Garcia N, Carillo S, Ta C, Roberts D, Comstock K, Lofthouse S, Ciceri E, D'Silva K, Kierans G, Kaisermayer C, Bones J. Large-scale assessment of extractables and leachables in single-use bags for biomanufacturing. Anal Chem. 2018. doi:10.1021/acs.analchem.8b01208. 
21. Eibl R, Steiger N, Fritz C, Eisenkrätzer D, Bär J, Müller D, Eibl D. Recommendation for Leachables Studies Standardized cell culture test for the early identification of critical films. Dechema Workgr. 2014:1-24.

22. Evaluating the toxicity of bDtBPP on CHOĞK1 cells for testing of singleĞuse bioprocessing systems.pdf.

23. Brian H, Liu TV, Weimin L, Xiao-Ping D, Kurt K, Frank G. A generic growth test method for improving quality control of disposables in industrial cell culture.

BioPharm Int. 2013;26(6):34-41.

24. Ding W, Madsen G, Mahajan E, O’Connor S, Wong K. Standardized Extractables Test hg Protocol for Single-Use Systems in Biomanufacturing. Pharm Eng. 2014;34(6):1-11.

25. Dorival-García N, Bones J. Monitoring leachables from single-use bioreactor bags for man malian cell culture by dispersive liquid-liquid microextraction followed by ultra . on performance liquid chromatography quadrupole time of flight mass spectrometry. - $r C L$ omatogr A. 2017;1512:51-60. doi:10.1016/j.chroma.2017.06.077.

26. Muller M. Use of reporter cell lines for detection of endocrine-disrupter activity. Anal Fivalal Chem. 2004;378(3):655-663. doi:10.1007/s00216-003-2217-2.

27. $4<4$ ell C, Elliott CT, Connolly L. Effects of the mycotoxin patulin at the level of $\mathrm{n}$ uclear receptor transcriptional activity and steroidogenesis in vitro. Toxicol Lett. 201/229(2):366-373. doi:10.1016/j.toxlet.2014.06.847.

28. Frizzell C, Ndossi D, Kalayou S, Eriksen GS, Verhaegen S, Sørlie M, Elliott CT, tad E, Connolly L. An in vitro investigation of endocrine disrupting effects of the myc toxin alternariol. Toxicol Appl Pharmacol. 2013;271(1):64-71. do1:10.1016/j.taap.2013.05.002.

29. Ar ia T, Hilscherova K, Jones PD, Newsted JL, Zhang X, Hecker M, Higley EB, San'erson JT, Yu RMK, Wu RSS, Giesy JP. The H295R system for evaluation of endocrine-disrupting effects. Ecotoxicol Environ Saf. 2006;65(3):293-305. do1:10.1016/j.ecoenv.2006.06.012.

30. Kalayou S, Hamre AG, Ndossi D, Connolly L, Sørlie M, Ropstad E, Verhaegen S. Usir g SILAC proteomics to investigate the effect of the mycotoxin, alternariol, in the an H295R steroidogenesis model. Cell Biol Toxicol. 2014;30(6):361-376. doi. $0.1007 / \mathrm{s} 10565-014-9290-5$.

31. Tunández-Blanco C, Frizzell C, Shannon M, Ruiz MJ, Connolly L. An in vitro inve tigation on the cytotoxic and nuclear receptor transcriptional activity of the otoxins fumonisin B1 and beauvericin. Toxicol Lett. 2016;257:1-10. doj $\cdot{ }^{11} 0.1016 /$ j.toxlet.2016.05.021.

32. V iśniewski JR, Zougman A, Nagaraj N, Mann M. Universal sample preparation motblod for proteome analysis. Nat Methods. 2009;6(5):359-362. doi:10.1038/nmeth.1322.

33. Colemen O, Henry M, Clynes M, Meleady P. Filter-Aided Sample Preparation (FASP) for Improved Proteome Analysis of Recombinant Chinese Hamster Ovary Cells. In: Heterologous Protein Production in CHO Cells. ; 2017:187-194. 
https://link.springer.com/book/10.1007/978-1-4939-6972-2.

34. Kaushik P, Henry M, Clynes M, Meleady P. The expression pattern of the phosphoproteome is significantly changed during the growth phases of recombinant CHO cell culture. Biotechnol J. 2018:1700221. doi:10.1002/biot.201700221.

35. Ngo JK, Pomatto LCD, Davies KJA. Upregulation of the mitochondrial Lon Protease allows adaptation to acute oxidative stress but dysregulation is associated with chronic stress, disease, and aging\$. Redox Biol. 2013;1(1):258-264. doi:10.1016/j.redox.2013.01.015.

36. Iepke D, Castner J, Egert T, Feinberg T, Hendricker A, Houston C, Hunt DG, Lynch M, haw A, Nicholas K, Norwood DL, Paskiet D, Ruberto M, Smith EJ, Holcomb F. Euractables Characterization for Five Materials of Construction Representative of T maging Systems Used for Parenteral and Ophthalmic Drug Products. Vol 67.; 2013. doi:10.5731/pdajpst.2013.00933.

37. Mughitoiu, L., Liu, J., Lee, H., Perez, L., Fujimori, K., Ronk, M., Hammond, MR., - H., Lower, A., Rogers, G., Nashed-Samuel Y. Extractables analysis of singleuse flexible plastic biocontainers. PDA J Pharm Sci Technol. 2015;69(1):49.58.

38. Pahl, I., Dorey, S., Barbaroux, M., Lagrange, B., Frankl H. Analysis and evaluation of Fomgre-use bag extractables for validation in biopharmaceutical applications. PDA J Pho'm Sci Technol. 2014;68(5):456-471.

39. Toxtree (Estimation of toxic hazard - a decision tree approach). http'/toxtree.sourceforge.net/.

40. U. S. Food and Drug Administration/Center for Biologics Evaluation and Research, Guidance for Industry Q3D Elemental Impurities. Food Drug Adm.

2015,(September):1-85.

41. Tan CZ, Yaniger SI, Jordan VC, Klein DJ, Bittner GD. Most plastic products release ast genic chemicals: A potential health problem that can be solved. Environ Health I Perspect. 2011;119(7):989-996. doi:10.1289/ehp.1003220.

42.

kovic I. Evaluation of safety and quality impact of extractable and leachable subs anges in therapeutic biologic protein products: a risk-based perspective. Expert Opin Diug Saf. 2007;6(5):487-491. ～doi:doi.org/10.1517/14740338.6.5.487.

43. No d J, Mahajan E, Shiratori M. Strategy for selecting disposable bags for cell culture media applications based on a root-cause investigation. Biotechnol Prog.

201 ;29(6):1535-1549. doi:10.1002/btpr.1802.

44. Dorival-García N, Bones J. Evaluation of solvent systems for optimized extractables stud es of single use bioprocessing solutions. J Chromatogr A. 2017;1513:69-77. do1:1,0.1016/j.chroma.2017.06.066.

45 unn $\mathrm{H}$, Hammond M. Impact of a toxic single-use bio-process container film 1. achable on Chinese hamster ovary cells. In: Single-USe Technologies: Bridging Polymer Science to Biotechnology Applications. ; 2015.

46. Ruberto MA. Polymers and Additives Used in Fabrication of Disposable Bioprocess Equipment. Bioprocess Int. 2010;(April):36-41.

47. Dorey S, Stedim S, Pahl I, Uettwiller I, Janvier S, Jurkiewicz E. 5 Limitation and 
detection of bis(2,4-di-tert- butylphenyl)phosphate (bDtBPP) from bioprocess container materials. In: Engineering Conferences International ECI Digital Archives. ; 2015. http://dc.engconfintl.org/biopoly.

48. Alin J, Hakkarainen M. Microwave heating causes rapid degradation of antioxidants in polypropylene packaging, leading to greatly increased specific migration to food simulants as shown by ESI-MS and GC-MS. J Agric Food Chem. 2011;59(10):54185427. doi:10.1021/jf1048639.

49. Farajzadeh MA, Bahram M, Jönsson JÅ. Dispersive liquid-liquid microextraction followed by high-performance liquid chromatography-diode array detection as an ffic ient and sensitive technique for determination of antioxidants. Anal Chim Acta. 200 ;591(1 SPEC. ISS.):69-79. doi:10.1016/j.aca.2007.03.040.

5(. analysis by HPLC. Chromatographia. 1998;48(7-8):491-496.

doi $0.1007 / \mathrm{BF} 02466639$.

56. plants - a comparative view. Physiol Plant. 2017;161(1):6-15. doi:10.1111/ppl.12561.

52. Fernandez-Martell A, Johari YB, James DC. Metabolic phenotyping of CHO cells Frary, ng in cellular biomass accumulation and maintenance during fed-batch culture.

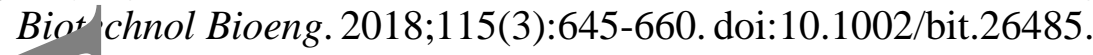

Fig. re ] egends

Figure 1: Impact of conditioned media from two single-use disposable bioreactor bags on the bioprocess-relevant phenotypes of CHO-K1 and CHO-DP12 cells. Cells were cultured i an 8-10 day batch process in chemically defined media (BalanCD CHO Grov $\ldots$ A) and analysed every 2 days for cell density and culture viability using the Guava racount Assay as well as for IgG production using ELISA. CHO-K1 cells cultured in media conditioned in the older F-1 film (A and B) and newer F-2 film (C and D) f $r$ days. CHO-DP12 Cells cultured in same F-1 (E-G) and F-2 (H-I) media conditioned. Control cells were cultured in media conditioned for the same 7 day timefrom but done so in glass bottles. An additional control "Fresh BalanCD" was inclu aed $y$ hich compares culture media not subjected to the conditioning process. $(n=$ 9, *** $P \leq 0.001, * P \leq 0.05)$.

Figure 2. Impact of conditioned media from two single-use disposable bioreactor bags on th oloprocess-relevant phenotypes of CHO-K1 and CHO-DP12 cells. Cells were cultured in an 8-10 day batch process in chemically defined media (BalanCD CHO Growth A) and analysed every 2 days for cell density and culture viability using the Guava ViaCount Assay as well as for IgG production using ELISA. CHO-K1 cells cultured in media conditioned in F-1 (A-B) and F-2 (C-D) films for 3 days. CHO-DP12 
cells cultured in media conditioned in F-1 (E-G) and F-2 (H-I) films for 3 days Control cells were cultured in media conditioned for the same 3 day timeframe but done so in glass bottles. An additional control "Fresh BalanCD" was included which compares culture media not subjected to the conditioning process. $(\mathrm{n}=9, * * * \boldsymbol{P} \leq 0.001, * \boldsymbol{P} \leq$ 0.05).

Figure 3: The number of both common and unique differentially expressed proteins identified through quantitative label-free LC-MS/MS proteomic analysis from CHO-K1 and $\mathrm{CH}$ CDP12 cells cultured in 7 day F-1 and F-2 film conditioned media and $h \quad 96$ hours into culture for proteomic analysis are represented in the Venn diag(am) A). Using the Seahorse FX96 analyser, CHO-K1 cells cultured in 7 day conditioned media in both F-1 and F-2 films were assessed for mitochondrial/TCA cycle activity by monitoring the oxygen consumption rate (OCR), B) as well as glycolytic metaholism through the assessment of the extracellular acidification rate (ECAR), C). Cells wert harvested for analysis 96 hours into culture and compared to control negat: media cultures. $(n=3)$.

Figure 4: 1) Comparative chart for identified non-volatile leachables in both evaluated SUB models. Comparative LC chromatograms from (B) F-1 and (C) F-2 films. Some compound that demonstrated higher levels in F-1 are highlighted, including bDtBPP, and dotails for these are shown in table 3. D) Comparative chart for identified elemental leachahl from both evaluate SUB models. E) Comparative chart for the identified conc......... ons of elemental leachable in both evaluated SUB models.

Figure 5: Impact of various elemental leachables on the bioprocess-relevant phenotypes of CFP-I 1 and the antibody-producing CHO-DP12 cell lines. Cells were cultured in chemicy defined (BalanCD CHO Growth A) media spiked on day 0 with the various elemental netal ( $\mathrm{Al}, \mathrm{Pb}, \mathrm{Ni}, \mathrm{Ag}$ and $\mathrm{Na}$ ) and harvested 96 hours into culture for growth and viability analysis using the Guava ViaCount Assay and IgG production using ELIS. Cetals were dissolved in water and spiked at a concentration of $1 \mathrm{mg} / \mathrm{L}$ in both CHO-K $-A$ ) and CHO-DP12 (C) cells on day 0 of culture and assessed for growth and viabint Various concentrations of silver $(\mathrm{Ag})$ ranging from $0.001-2 \mathrm{mg} / \mathrm{L}$ was spiked at day 0 in CHO-K1 (B) and CHO-DP12 (D) cultures and assessed for growth and viability. Additionally, in the case of CHO-DP12 cells, IgG productivity was assessed (E). $(\mathbf{n}=3, * * * P \leq 0.001, * P \leq 0.05)$. 
Figure 6: Antagonist effects of bDtBPP $(0.005-0.25 \mu \mathrm{g} / \mathrm{ml})$ in the androgen and progestagen responsive TARM-Luc cell line. The responses measured are compared to the solvent control (0.2\% DMSO) and the positive control (testosterone $288 \mathrm{ng} / \mathrm{ml}$ ). Percentage responses are expressed as \pm SEM for three independent exposures in triplicate $(\mathbf{n}=3), \mathbf{P}=<0.001(* * *)$.

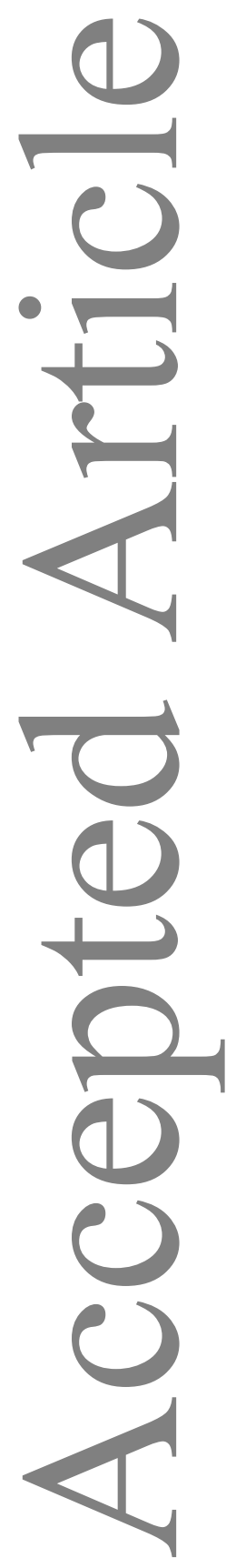


Figure 1

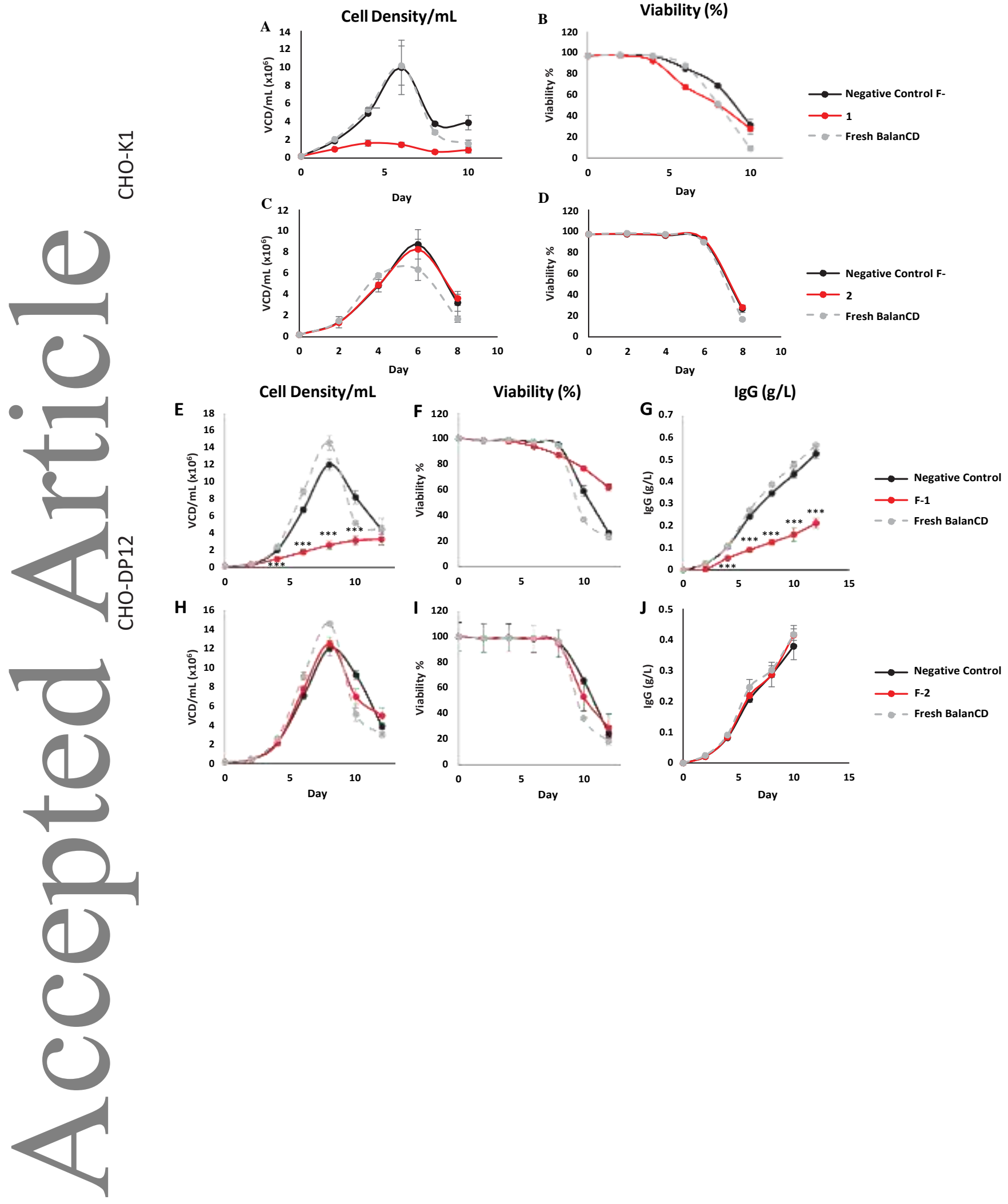

This article is protected by copyright. All rights reserved. 
Figure 2

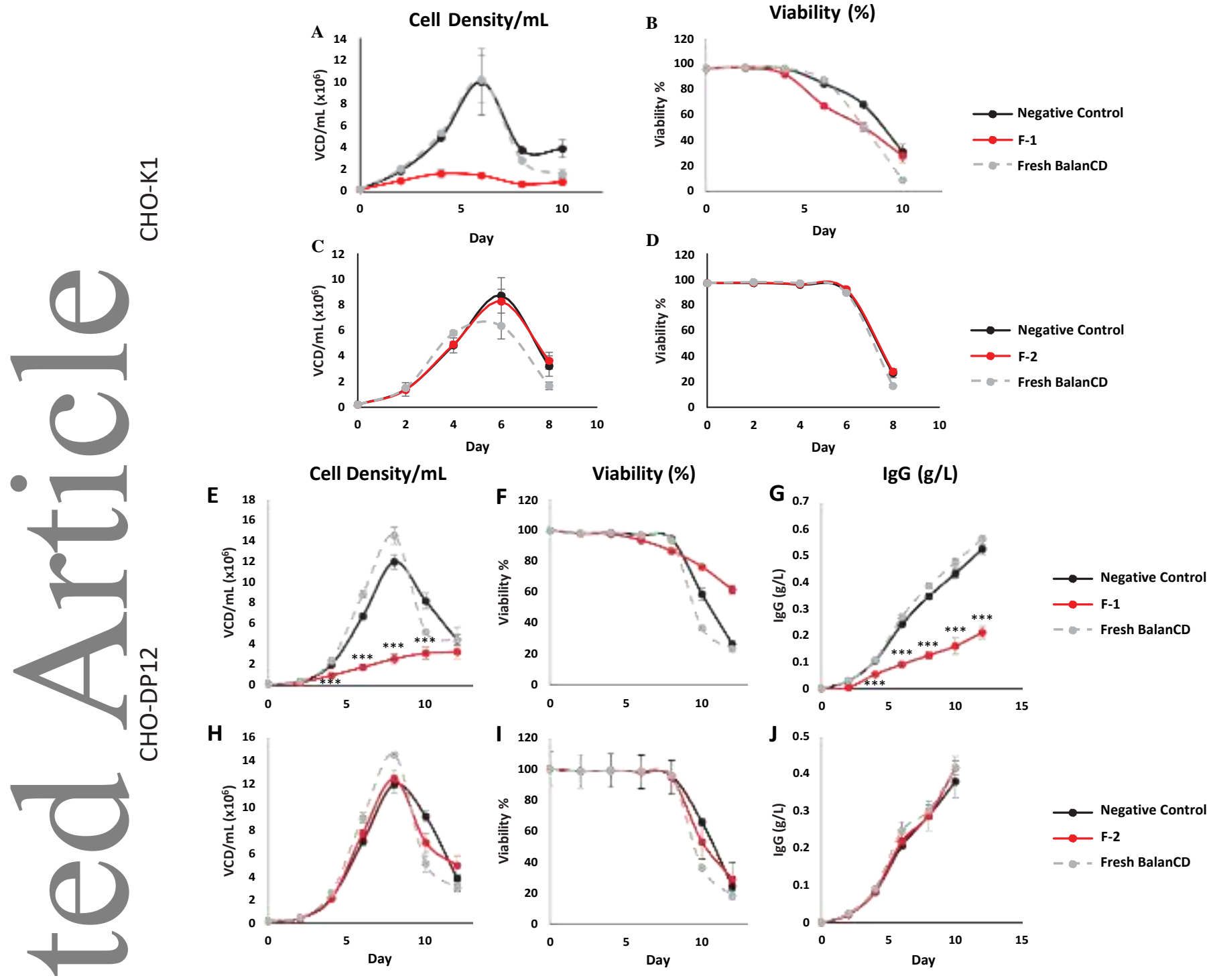

This article is protected by copyright. All rights reserved. 


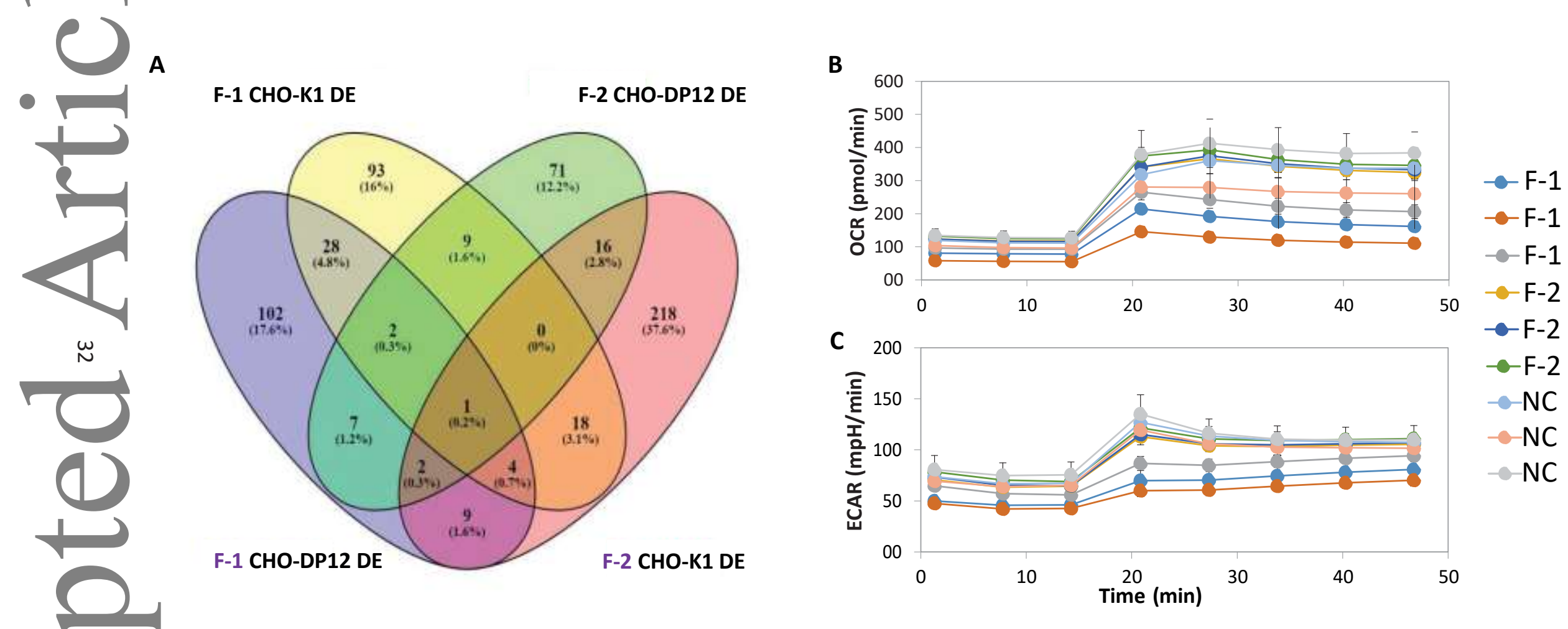


Figure 4

A)
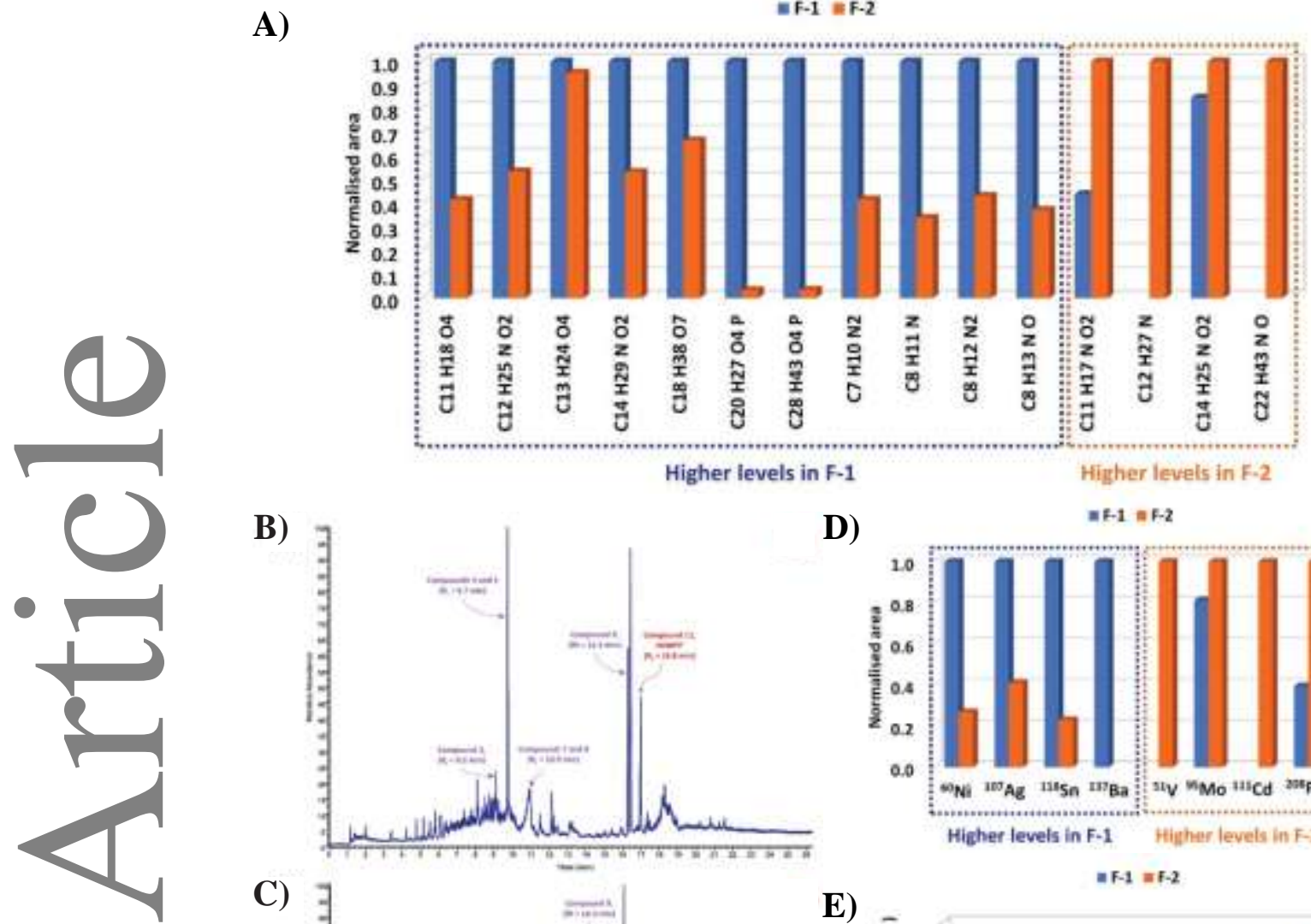

B)

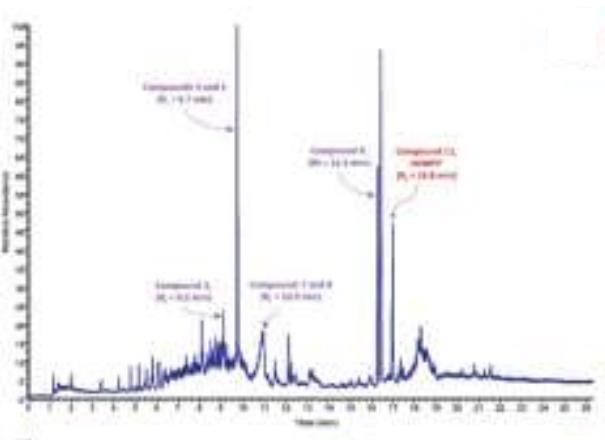

C)

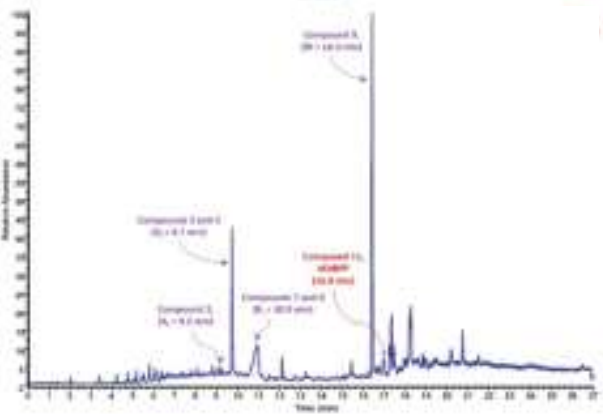

D)

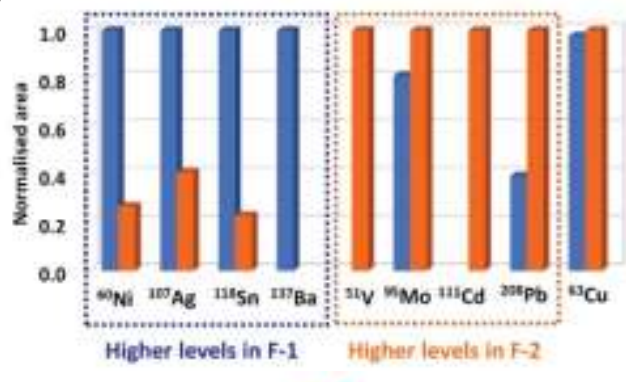

E)

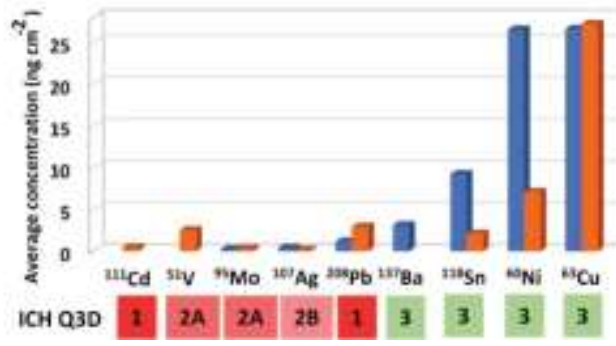


(1)
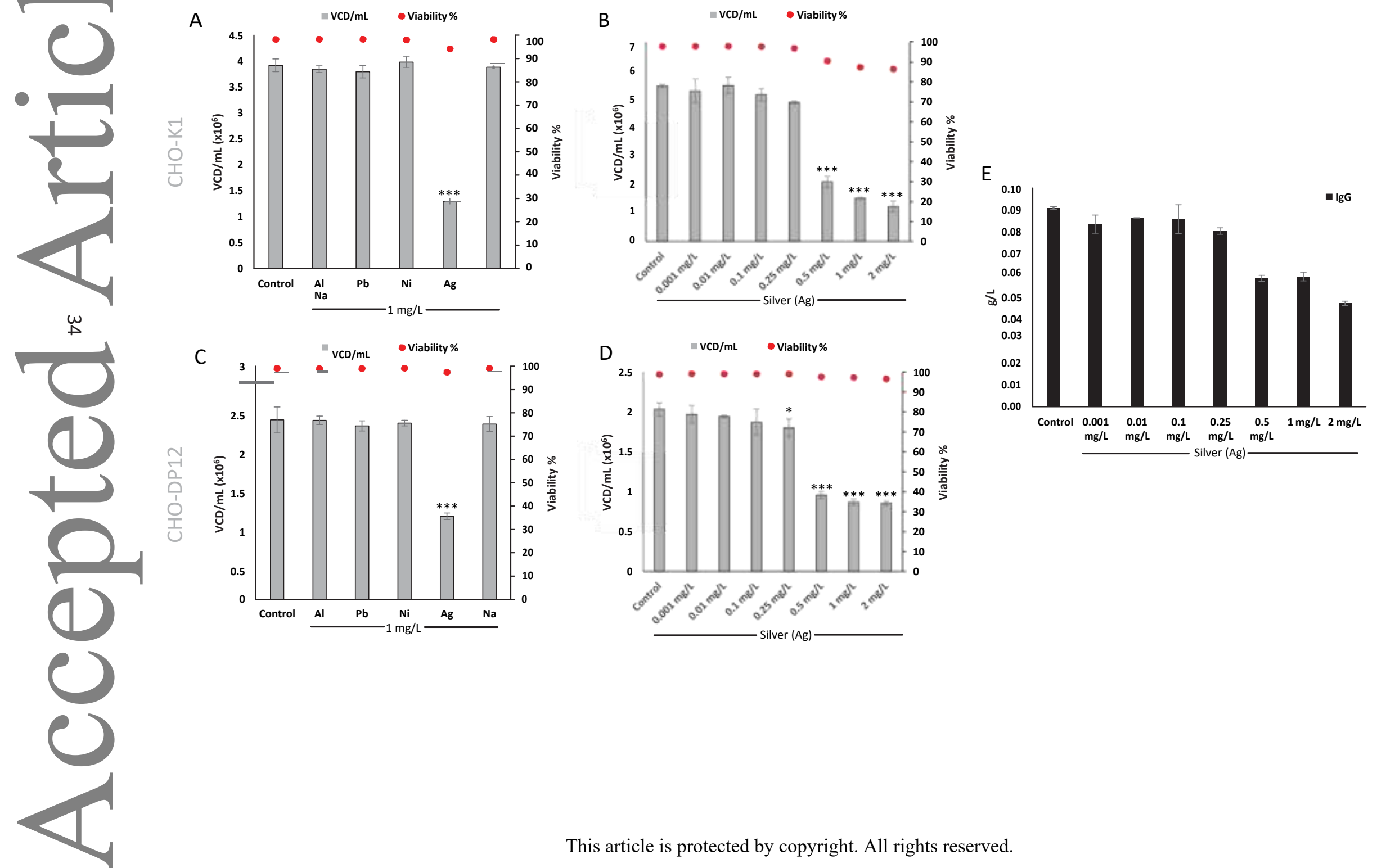

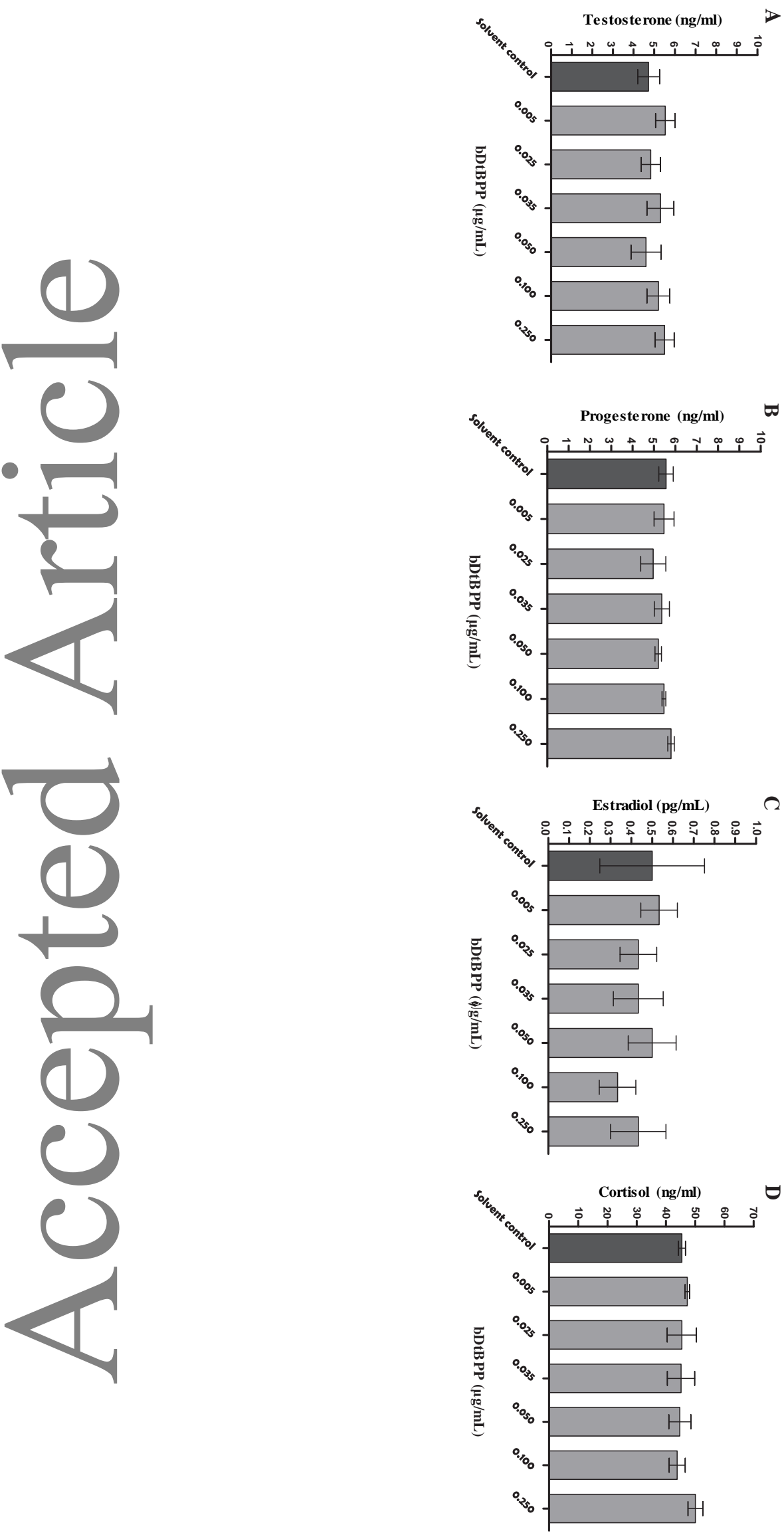

This article is protected by copyright. All rights reserved. 
Table 1: Common Differentially Expressed proteins in CHO cells incubated in F-1 film conditioned media

\begin{tabular}{|c|c|c|c|c|}
\hline Gene I.D. & UR/DR & FCCHO-DP12 & FССНО-К1 & \begin{tabular}{|l|} 
Biological Process \\
\end{tabular} \\
\hline NDUFS2 & DR & 4.17 & 1.51 & ATP synthesis \\
\hline NDUFS9 & DR & 2.55 & 1.70 & Electron transport \\
\hline NDUFV1 & DR & 2.30 & 1.66 & ATP synthesis \\
\hline NDUFA10 & DR & 2.17 & 1.68 & Electron transport \\
\hline PCK1 & UR & 1.59 & 2.04 & Glucose metabolism \\
\hline LONP1 & UR & 1.79 & 2.14 & Oxidative stress \\
\hline VNN1 & UR & 1.51 & 1.62 & Oxidative stress \\
\hline CHCHD1 & UR & 1.64 & 1.75 & \begin{tabular}{|ll}
$\begin{array}{l}\text { Mitochondrial translation } \\
\text { elongation }\end{array}$ & \\
\end{tabular} \\
\hline
\end{tabular}

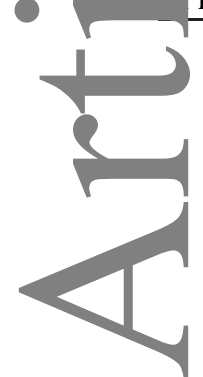

Table 2: Gene Ontology Analysis for Differentially Expressed proteins from CHOK1/DP12 F-1 conditioned media

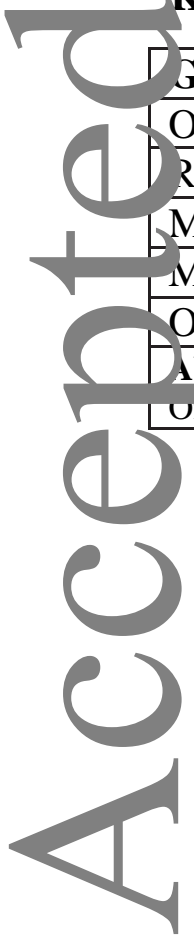




\section{Table 3}

Summary of identified leachables by LC-MS.

\begin{tabular}{|c|c|c|c|c|c|c|c|c|c|}
\hline & \multirow{3}{*}{ Compound name } & \multirow{3}{*}{ Formula } & \multirow{3}{*}{$\begin{array}{c}\text { Molecular } \\
\text { Weight }\end{array}$} & \multirow{3}{*}{ Annotation } & \multirow{3}{*}{$\begin{array}{l}\Delta \text { Mass } \\
{[\text { ppm] }}\end{array}$} & \multirow{3}{*}{ Tentative function } & \multirow{3}{*}{$\begin{array}{c}\text { Cramer } \\
\text { class }\end{array}$} & \multirow{2}{*}{\multicolumn{2}{|c|}{$\begin{array}{c}\begin{array}{c}\text { Carcinogenicity } \\
\text { alerts }\end{array} \\
\text { In silico(1) }\end{array}$}} \\
\hline & & & & & & & & & \\
\hline & & & & & & & & A & B \\
\hline 1 & N,N-di(2-hydroxyethyl)-p-toluidine & $\mathrm{C}_{11} \mathrm{H}_{17} \mathrm{NO}_{2}$ & 195.12611 & $3077-12-1$ & 0.92 & Photopolymerization/adhesive & 3 & NO & NO \\
\hline \multirow[b]{2}{*}{2} & 1,4-dioxacyclotridecane-5,13-dione & \multirow[b]{2}{*}{$\mathrm{C}_{11} \mathrm{H}_{18} \mathrm{O}_{4}$} & \multirow[b]{2}{*}{214.12025} & $4471-27-6$ & \multirow[b]{2}{*}{1.20} & Adhesive for multilayer materials & 1 & NO & NO \\
\hline & 3,3-Dimethyl-1,5-dioxacycloundecane-6,11-dione & & & $94113-47-0$ & & $\begin{array}{l}\text { Contamination formed in polyolefin } \\
\text { containers }\end{array}$ & 1 & NO & NO \\
\hline 3 & 1,2-amidododecanoic acid & $\mathrm{C}_{12} \mathrm{H}_{25} \mathrm{NO}_{2}$ & 215.18841 & $693-57-2$ & 0.56 & Residue from production & 1 & NO & NO \\
\hline 4 & $\mathrm{~N}, \mathrm{~N}$-dimethyldecan-1-amine & $\mathrm{C}_{12} \mathrm{H}_{27} \mathrm{~N}$ & 185.21452 & $1120-24-7$ & 0.90 & Catalyst degradation product & 1 & NO & NO \\
\hline \multirow[t]{2}{*}{5} & Ethylmalonic acid dibutyl ester & \multirow{2}{*}{$\mathrm{C}_{13} \mathrm{H}_{24} \mathrm{O}_{4}$} & \multirow[t]{2}{*}{244.16699} & $1113-92-4$ & \multirow[t]{2}{*}{1.93} & $\begin{array}{l}\text { Propylene copolymer, residue from } \\
\text { production }\end{array}$ & 1 & NO & YES \\
\hline & Diethyl azelate & & & $624-17-9$ & & Plasticizer & 1 & NO & NO \\
\hline 6 & $\begin{array}{l}\text { 2-Propenoic acid 2-methyl- 1,2,2,6,6-pentamethyl-4- } \\
\text { piperidinyl ester }\end{array}$ & $\mathrm{C}_{14} \mathrm{H}_{25} \mathrm{NO}_{2}$ & 239.18838 & 68548-08-3 & 0.62 & UV stabilizer & 3 & NO & NO \\
\hline 7 & $\mathrm{~N}$-(2-hydroxyethyl)-dodecanamide & $\mathrm{C}_{14} \mathrm{H}_{29} \mathrm{NO}_{2}$ & 243.21957 & $142-78-9$ & 1.07 & Antistatic agent & 3 & NO & NO \\
\hline 8 & PPG n6 & $\mathrm{C}_{18} \mathrm{H}_{38} \mathrm{O}_{7}$ & 366.26130 & 25322-69-4 & 1.23 & Polymer block degradation product & 3 & NO & NO \\
\hline 9 & 2-Ethylhexyldiphenyl phosphate (Santicizer ${ }^{\oplus}$ ) & $\mathrm{C}_{20} \mathrm{H}_{27} \mathrm{O}_{4} \mathrm{P}$ & 362.16400 & $1241-94-7$ & 1.93 & Flame retardand, plasticizer & 3 & NO & YES \\
\hline 10 & cis-1,3-docosenic acid amide (Kemamide ${ }^{\circledast}$ E ultra) & $\mathrm{C}_{22} \mathrm{H}_{43} \mathrm{NO}$ & 337.33386 & $112-84-5$ & 1.78 & Slip agent & 3 & NO & NO \\
\hline 11 & bis(2,4-di-tert-butylphenyl)phosphate (bDtBPP) & $\mathrm{C}_{28} \mathrm{H}_{43} \mathrm{O}_{4} \mathrm{P}$ & 474.28925 & 69284-93-1 & 1.37 & Antioxidant degradation product & 3 & NO & NO \\
\hline \multirow{2}{*}{12} & 2,6-Toluenediamine & \multirow{2}{*}{$\mathrm{C}_{7} \mathrm{H}_{10} \mathrm{~N}_{2}$} & \multirow{2}{*}{122.08440} & $823-40-5$ & \multirow{2}{*}{0.05} & Polyurethane intermediate & 3 & YES & NO \\
\hline & 2,4-Toluenediamine & & & 95-80-7 & & Polyurethane intermediate & 3 & YES & NO \\
\hline \multirow[t]{2}{*}{13} & 5-Ethyl-2-methyl-pyridine & \multirow[t]{2}{*}{$\mathrm{C}_{8} \mathrm{H}_{11} \mathrm{~N}$} & \multirow[t]{2}{*}{121.08917} & $104-90-5$ & \multirow[t]{2}{*}{0.18} & $\begin{array}{l}\text { Vinyl acetate catalyst/olefin epoxidation } \\
\text { catalyst / solvent for polycarbonate } \\
\text { polymerisation }\end{array}$ & 3 & NO & NO \\
\hline & 2,4-Dimethyl-aniline & & & 95-68-1 & & Catalyst degradation product & 3 & YES & NO \\
\hline \multirow[b]{2}{*}{14} & 1,3-Bis(aminomethyl)benzene & \multirow[b]{2}{*}{$\mathrm{C}_{8} \mathrm{H}_{12} \mathrm{~N}_{2}$} & \multirow[b]{2}{*}{136.10023} & $1477-55-0$ & \multirow[b]{2}{*}{1.34} & Polyamide modification agent & 3 & NO & NO \\
\hline & Tetramethyl succinonitrile & & & $3333-52-6$ & & $\begin{array}{l}\begin{array}{l}\text { Polymerization initiator degradation } \\
\text { product }\end{array} \\
\end{array}$ & 3 & NO & NO \\
\hline 15 & 1-ethenylazepan-2-one & $\mathrm{C}_{8} \mathrm{H}_{13} \mathrm{NO}$ & 139.09981 & $2235-00-9$ & 0.67 & Coating & 3 & NO & NO \\
\hline 16 & Tris(2,4-di-tert-butylphenyl)phosphate & $\mathrm{C}_{42} \mathrm{H}_{63} \mathrm{O}_{4} \mathrm{P}$ & 662.44640 & 95906-11-9 & 1.22 & Antioxidant degradation product & 3 & $N A^{(2)}$ & $\mathrm{NA}^{(2)}$ \\
\hline
\end{tabular}

(1) From Toxtree using Benigni/Biossa rulebase $A$ = considering genotoxic effects, $B=$ considering non-genotoxic effects.

(2) $\mathrm{NA}=$ Not available.

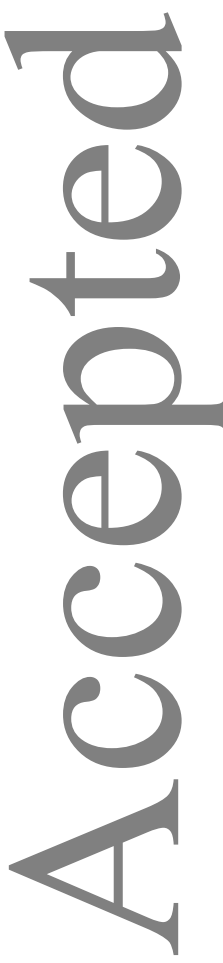

This article is protected by copyright. All rights reserved. 